\title{
Synthesis of substituted 5'-aminoadenosine derivatives and evaluation of their inhibitory potential towards CD73
}

\author{
R. Ghoteimi, ${ }^{\$[a]}$ T. Nguyen Van, ${ }^{\$[a]}$ R. Rahimova, ${ }^{[b]}$ F. Grosjean, ${ }^{[a]}$ E. Cros-Perrial, ${ }^{[c]}$ J.-P. Uttaro, ${ }^{[a]}$ C. \\ Mathé, ${ }^{[a]}$ L. Chaloin, ${ }^{[b]}$ L.P. Jordheim, ${ }^{[c]}$ and S. Peyrottes ${ }^{*[a]}$
}

\$ These authors contributed equally to this work
[a] R. Ghoteimi, Dr T. Nguyen Van, F. Grosjean, Dr J.-P. Uttaro, Prof. C. Mathé, Dr S. Peyrottes, ORCID: 0000-0003-1705-0576 Institut des Biomolécules Max Mousseron (IBMM), UMR 5247 CNRS, Univ. Montpellier, ENSCM
Campus Triolet, cc1705, Place Eugène Bataillon, 34095 Montpellier, France
E-mail: suzanne.peyrottes@umontpellier.fr
[b] Dr R. Rahimova, Dr L. Chaloin, ORCID: 0000-0002-5757-5804
Institut de Recherche en Infectiologie de Montpellier (IRIM), Univ. Montpellier, CNRS
34293 Montpellier, France
[c] E. Cros-Perrial, Dr L.P. Jordheim, ORCID: 0000-0003-3948-7090
Univ. Lyon, Université Claude Bernard Lyon 1, INSERM 1052, CNRS 5286
Centre Léon Bérard, Centre de Recherche en Cancérologie de Lyon
69008 Lyon, France
Supporting information for this article is given via a link at the end of the document

\begin{abstract}
Derivatives of 5'-amino-adenosine containing methyl carboxylate, methyl phosphonate, gem-bisphosphonate, bis(methylphosphonate), and $\alpha$-carboxylmethylphosphonate or phosphonoacetic moieties were synthesized from a key intermediate 5 '-aminonucleoside. These nucleos(t)ide analogues were envisaged as $5^{\prime}$-mono or diphosphate nucleoside mimics. All compounds were evaluated for CD73 inhibition in a cell-based assay (MDA-MB-231) and towards the purified recombinant protein. Most of them failed to reach significant inhibition of AMP hydrolysis by CD73 at $100 \mu \mathrm{M}$. Among the new compounds, the most interesting ones were derivatives 5 and 7 , inhibiting recombinant CD73 by 36 and $47 \%$ and cellular CD73 by 61 and $45 \%$ at $100 \mu \mathrm{M}$, respectively. Molecular modeling allowed to explain partially this lack of activity as predicted docking score calculated beforehand were initially encouraging, especially for compound 7 .
\end{abstract}

\section{Introduction}

Ecto-5'-nucleotidase CD73 is a glycophosphatidyl-inositolanchored di- $\mathrm{Zn}^{2+}$ metallo-phosphatase. It is an important enzyme involved in the extracellular catabolism of nucleosides and nucleotides working together with the membrane-bound CD39. The latter catalyzes the dephosphorylation of ATP into AMP, whereas CD73 dephosphorylates extracellular AMP into adenosine and inorganic phosphate. Thus, CD73, as a modulator of adenosine production, has been identified as an active player and a validated drug target in several diseases, such as cancer, autoimmunity, allergy and ischemia-reperfusion injury. ${ }^{[1]}$ Numerous studies have shown that the inhibition of CD73 activity, both in mice models and in cell cultures, by a substrate analogue mimicking ADP (APCP, 5'-methylenebisphosphonate adenosine, Figure 1), a monoclonal antibody or siRNA, is associated with decreased tumor growth and metastasis development, decreased tumor angiogenesis and increased activity of immune-modulating therapeutic antibodies. ${ }^{[2]}$ In the last few years, exciting progress in the development of immunotherapy for the treatment of cancer patients have been achieved. Thus, modulation of the immune system through a small-molecule approach offers several unique advantages (lower cost, facilitated administration...) being complementary to and potentially synergistic with immuneoncology approaches using monoclonal antibodies. ${ }^{[3]}$ This is exemplified by the association of two mAbs, one targeting CD73 (MEDI-9447 $7^{[4]}$ ) and one neutralizing the immune check point PD1. However, approaches currently using small molecules to inhibit CD73 activity are not yet suitable for clinical use. Indeed, one of the first and well-known small molecule inhibitor (APCP) has low bioavailability, poor metabolic stability and off-target related effects presumably associated with chemical instability and adenosine release. ${ }^{[5]}$ To our knowledge, the most potent inhibitors of CD73 were described by the team of Prof. Müller and are structurally related to the APCP skeleton (Figure 1). ${ }^{[6]}$ In addition, nucleoside analogues incorporating two carboxylate groups have been patented. ${ }^{[7]}$ However, no data are available on the in vivo activity of these two series of compounds. Therefore, it is still of great interest to design new smallmolecule CD73 inhibitors.

Study of APCP in the active site of CD73 (Figure 2) showed key structural interactions with the terminal domains in the substrate binding site. ${ }^{[8]}$ The adenine-base formed hydrophobic $\pi$-stacking interaction between two phenylalanine residues (F417 and F500), and the diol group of the ribose interacts mainly with D506. The a-phosphonate group binds with R354 and N245 residues, whereas the $\beta$-phosphonate group binds to $\mathrm{R} 395$ of $\mathrm{C}$ terminal domain as well as to $\mathrm{N} 85$ and $\mathrm{H} 243$ of the $\mathrm{N}$-terminal domain. In addition, $\alpha, \beta$-phosphonate groups chelate the two $\mathrm{Zn}^{2+}$ ions through the formation of monodentate and bidentate interactions. Based on these observations and as illustrated in Figure 1, two types of nucleos(t)ide analogues were designed using adenosine as scaffold. In particular, 5'-amino-adenosine was selected as the nitrogen atom allows di-substitution or formation of additional $\mathrm{H}$-bond interaction. Thus, compounds $\mathbf{1}$, $\mathbf{4}$ and $\mathbf{5}$ incorporate either a carboxylate or a phosphonate group that may be viewed as equivalent of the phosphate of AMP (the 
natural CD73 substrate). In order to mimic the interaction of the $\alpha, \beta$-methylene diphosphate group of APCP with R354 and N245, a carboxyl oxygen or a phosphoryl oxygen was present in derivatives 2, 3, and 6-9, whereas the two oxygen atoms of the phosphonate group of bis(methylphosphonate), $\alpha$-carboxylmethylphosphonate or phosphonoacetic moieties may mimic the chelation of the $\mathrm{Zn}^{2+}$ ions by the $\beta$-phosphonate of APCP.

We report herein the synthesis of novel series of $\mathrm{N}$-substituted, 5'-amino-adenosine derivatives (compounds 1-9, Figure 1) as potential AMP or ADP mimics and evaluate their potential as CD73 inhibitors in vitro.
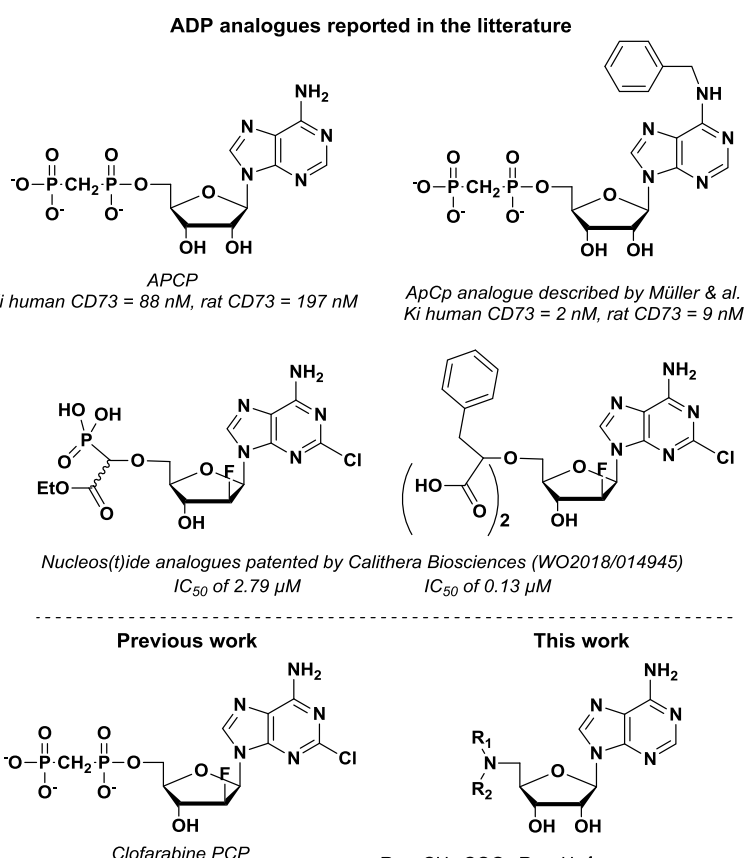

Clofarabine $P C P$ $1 C_{50}$ of $0.18 \pm 0.04 \mathrm{mM}$ (APCP: $1 C_{50}$ of $3.8 \pm 0.9 \mathrm{mM}$ ) Ki human $C D 73=2 \mathrm{nM}$, rat $C D 73=9 \mathrm{nM}$

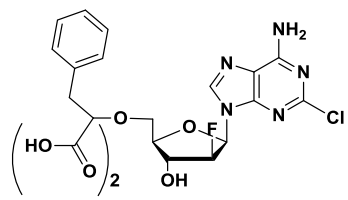

lithera Biosciences (WO2018/014945) $\mathrm{IC}_{50}$ of $0.13 \mu \mathrm{M}$

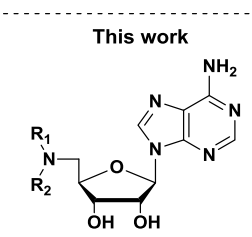

$\mathrm{R}_{1}=\mathrm{CH}_{2}-\mathrm{COO}^{-} \cdot \mathrm{R}_{2}=\mathrm{H}, 1$

$R_{1}=\mathrm{COCH}_{2}-\mathrm{P}(\mathrm{O}) \mathrm{OEt}\left(\mathrm{O}^{-}\right), \mathrm{R}_{2}=\mathrm{H}, 2$
$\mathrm{R}_{1}=\mathrm{COCH}_{2}-\mathrm{P}(\mathrm{O})\left(\mathrm{O}^{-}\right)_{2}, \mathrm{R}_{2}=\mathrm{H}, 3$

$\mathrm{R}_{1}=\mathrm{CH}_{2}-\mathrm{P}(\mathrm{O}) \mathrm{OEt}\left(\mathrm{O}^{-}\right), \mathrm{R}_{2}=\mathrm{H}, 4$

$\mathrm{R}_{1}=\mathrm{CH}_{2}-\mathrm{P}(\mathrm{O})(\mathrm{O})_{2}, \mathrm{R}_{2}=\mathrm{H}, 5$

$\mathrm{R}_{1}=\mathrm{R}_{2}=\mathrm{CH}_{2}-\mathrm{P}(\mathrm{O})\left(\mathrm{O}^{-}\right)_{2}, 6$

$\mathrm{R}_{1}=\mathrm{CH}(\mathrm{COO}-) \mathrm{P}(\mathrm{O}) \mathrm{OEt}\left(\mathrm{O}^{-}\right), \mathrm{R}_{2}=\mathrm{H}, 7$

$\mathrm{R}_{1}=\mathrm{CH}(\mathrm{COO}-) \mathrm{P}(\mathrm{O})\left(\mathrm{O}^{-}\right)_{2}, \mathrm{R}_{2}=\mathrm{H}, 8$

$\mathrm{R}_{1}=\mathrm{CH}\left[\mathrm{P}(\mathrm{O})\left(\mathrm{O}^{-}\right)_{2}\right]_{2}, \mathrm{R}_{2}=\mathrm{H}, 9$

Figure 1. Structures of ADP analogues as potent CD73 inhibitors and studied compounds 1-9.

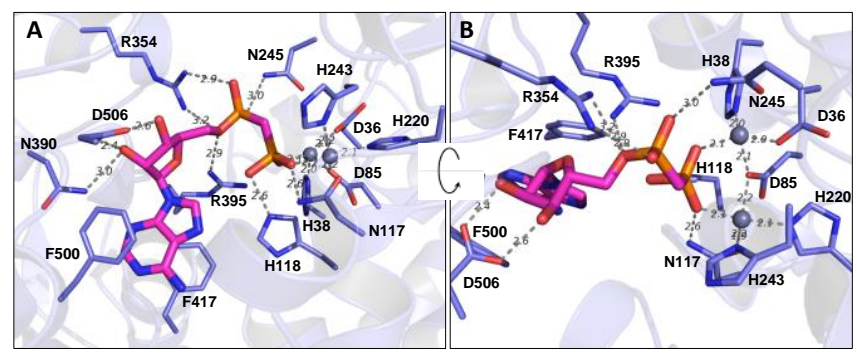

Figure 2. APCP binding mode within the active site of CD73 (crystal structure of the closed form solved by Knapp et al. ${ }^{[8]}$ ). A) and B) correspond to two orientations. APCP is depicted as pink sticks while connecting residues are shown in blue thin sticks and zinc ions as grey spheres.

\section{Results and Discussion}

\section{Synthesis}

The synthesis of adenosine analogues 1-8 began with 5'-amino2',3'-O-isopropylidene-adenosine 10 (Schemes 1 \& 2), which can be easily accessed in three steps from commercially available adenosine with overall yield about $71 \% .{ }^{\left[{ }^{[9]}\right.}$ Synthesis of derivatives 1 to 5 (Scheme 1) was envisaged through nucleophilic displacement by using methyl bromoacetate ${ }^{[10]}$ or diethyl $p$-toluene sulfonyloxymethylphosphonate (obtained before ${ }^{[11]}$ ) in presence of a base (either $\mathrm{NEt}_{3}$ or $\mathrm{DBU}$ ), or coupling of diethylphosphonoacetic $\mathrm{acid}^{[12]}$ using previously described or adapted conditions. Attempts to obtain disubstituted derivatives, by increasing the number of equivalents and/or reaction time, and temperature were unsuccessful. Concerning the synthesis of compound 1, the 5'-deoxy-2,3-O(isopropylidene)-5'- $N$-methyl-acetate-5'-aminoadenosine was contaminated with triethylammonium salts and directly engaged in the next step leading to $\mathrm{N}$-alkylated derivative in $45 \%$ yield over the two steps. The latter was treated with an equimolar amount of $1 \mathrm{M} \mathrm{NaOH}$ to afford derivative 1. Intermediates 11 and 13 were isolated in good yields, and removal of the sugarprotecting group in acidic conditions afforded derivatives 12 and 14 in 90 and $33 \%$ yields, respectively. Deprotection of the diethylphosphonoester group for compounds 12 and 14 was performed with TMSBr in DMF (Scheme 1). Partially deprotected derivatives were eventually isolated such as compounds $\mathbf{3}$ and $\mathbf{4}$, as well as the desired phosphonic acids $\mathbf{2}$ and $\mathbf{5}$, which were obtained as sodium salts through ion-exchange on Dowex $\left(\mathrm{Na}^{+}\right.$ form).

Synthesis of derivative 6 incorporating two phosphonomethyl groups and derivatives $\mathbf{7}$ and $\mathbf{8}$ incorporating a carboxylate and a phosphonate groups was also carried out starting from 5'amino-5'-deoxy-2',3'-O-isopropylidene-adenosine 10 (Scheme 2). The double Kabachnik-Fields reaction of $\mathbf{1 0}$, paraformaldehyde, and diethyl phosphite was performed under microwave activation and solvent-free conditions. ${ }^{[13]}$ The resulting derivative was directly treated in acidic conditions to afford compound $\mathbf{1 5}$ in $31 \%$ yield over the two steps. Then, removal of the phosphonic protecting groups was carried out as previously described and the desired 5'- $N$-[bisphosphonomethyl] adenosine 6 was obtained quantitatively.

The $\alpha$-carboxyphosphonate derivative 16 was obtained by using the Aza-Pudovick reaction, consisting in the addition of diethylphosphite to the in situ generated imine from 10 and ethylglyoxylate. This step was also performed under microwaveassisted and solvent-free conditions as described in the literature. ${ }^{[14]}$ Removal of the various protecting groups was carried out successively under acidic conditions, affording compound 17, and then in presence of TMSBr. During this last step, the $\alpha$-carboxy(monoethyl)phosphonate ester 7 was isolated as major derivative after 31 hours, whereas formation of the fully deprotected derivative 8 required 6 days of reaction. In both case, $\alpha$-carboxyphosphonate derivatives 7 and 8 were isolated as equimolar mixture of the two diastereoisomers. 




Scheme 1. Synthetic pathways for derivatives 1-5.

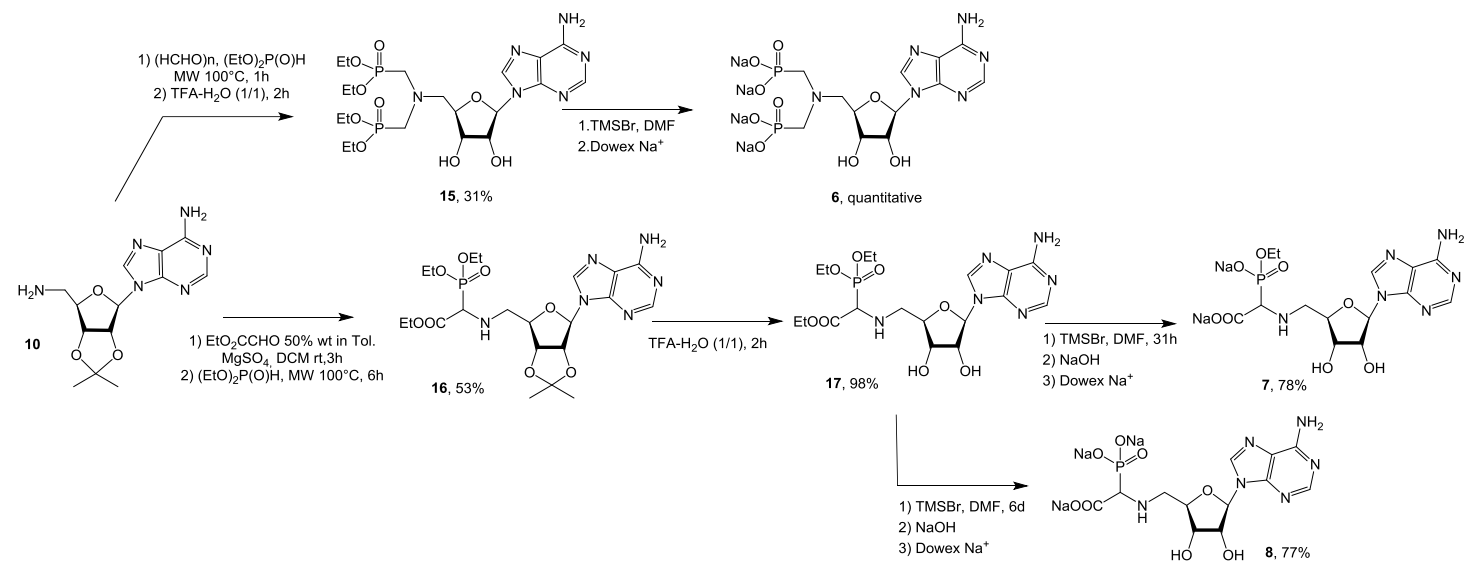

Scheme 2. Synthetic pathways for derivatives 6-8.

Preparation of (aminomethylene)bisphosphonate derivative $\mathbf{9}$ (Scheme 3) was envisaged through a three-component condensation involving 10, triethyl orthoformate and diethyl phosphite. ${ }^{[15]}$ Despite several attempts, only small amounts of the desired compound were obtained and formation of the bisadduct corresponding to the reaction of the exocyclic amino function of the purine ring was also observed. Thus, the use of a fully protected precursor appeared necessary. Protection of the amino group in position 6 of the 2',3'-O-isopropylideneadenosine by the 2,5-dimethylpyrrole was selected as it can be hydrolyzed in the same conditions as of the ribose protecting group. Thus, compound $\mathbf{1 8}$ was obtained in $36 \%$ yield from commercially available adenosine, according to previously published procedure. ${ }^{[16]}$ Then azidation in position 5' was performed and compound $\mathbf{1 9}$ was subjected to hydrogenation to afford the 9-(5-amino-5-deoxy-2,3-O-isopropylidene- $\beta$-Dribofuranosyl)-6-(2,5-dimethylpyrrol-1-yl)purine 20 . With this fully protected intermediate in hand, the method elaborated by $\mathrm{E}$. Balint et al. ${ }^{[15]}$ was successfully applied to a nucleosidic substrate, affording the gem(bisphosphonate) derivative 21 in $34 \%$ yield. Final steps consisted in removal of the various protecting groups as previously reported and lead to the target compound $\mathbf{9}$. 

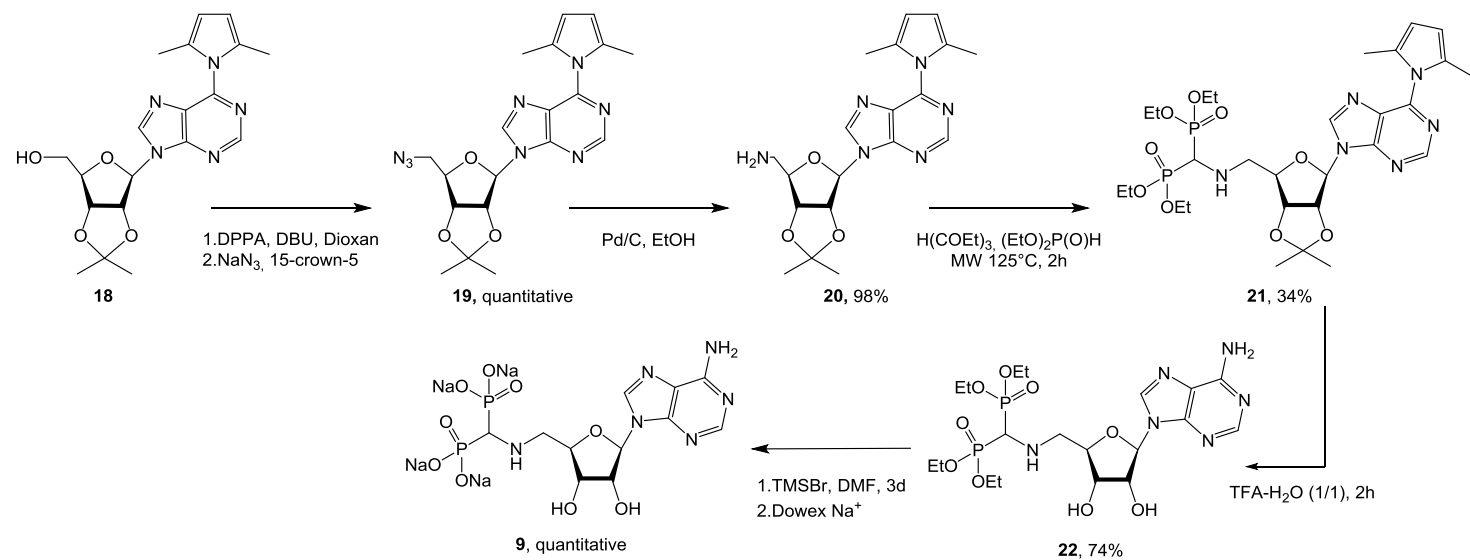

22, $74 \%$

Scheme 3. Synthesis of derivative 9.

In addition to compounds 1-9, we synthesized two analogues, such as the $\alpha$-carboxyphosphonate derivative of adenosine as a reference (Figure 3, compound 23), to study the impact of the nitrogen atom in position 5' (in comparison to compound 8), and the analogue of derivative 6 incorporating Clofarabine (Figure 3 , compound 24) instead of adenosine to study the influence of the nucleosidic residue. Indeed, literature data ${ }^{[7 a, 17]}$ tend to show that the use of Clofarabine as nucleoside scaffold led to increased potency for 5'-ectonucleotidase inhibition (cf. Clofarabine PCP, Figure 1). Synthetic pathways of these two derivatives are detailed in the $\mathbf{S I}$ as compound $\mathbf{2 3}$ has already been reported in the literature ${ }^{[18]}$ and compound $\mathbf{2 4}$ was obtained by adapting procedure described in Scheme 2 .
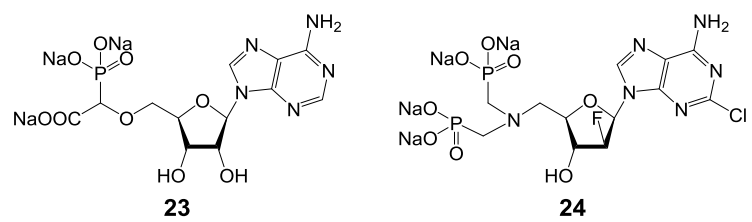

Figure 3. Structures of compounds 23 and 24.

\section{Inhibitory activity of synthesized compounds towards CD73}

The enzymatic activity of CD73 was assessed in presence of all adenosine-based derivatives to determine their potential inhibitory effect on CD73. Inhibition levels promoted by the compounds are shown in Table 1 at 10 or $100 \mu \mathrm{M}$ with recombinant protein, and at $100 \mu \mathrm{M}$ in the cell based assay. Compounds 1-4, 6 and 8 inhibited CD73 activity only weakly at high concentration (between $10-44 \%$ of inhibition) in both conditions. Compounds 5, 7, 9 and 24 exhibited a moderate enzymatic inhibition with inhibition values ranging from 45 to $61 \%$ at $100 \mu \mathrm{M}$ in at least one of the two assays. In contrast, derivative $\mathbf{2 3}$ was found to promote a strong inhibition on both recombinant $(76 \pm 3 \%)$ and cellular $(82 \pm 4 \%)$ CD73 at high concentrations, and still significantly $(35 \pm 4 \%)$ at $10 \mu \mathrm{M}$ (Figure $4 \mathrm{~A})$. As expected, APCP, as well as our previously developed inhibitor Clofarabine $\mathrm{PCP},{ }^{[17]}$ used here as positive controls, were able to inhibit CD73 activity by more than $90 \%$ at high concentrations. MTT assays were performed with MDA-MB-231 cells and studied compounds to estimate cytotoxicity, and showed marginal (76\% survival for compound 3 ) or no such effect (data not shown).
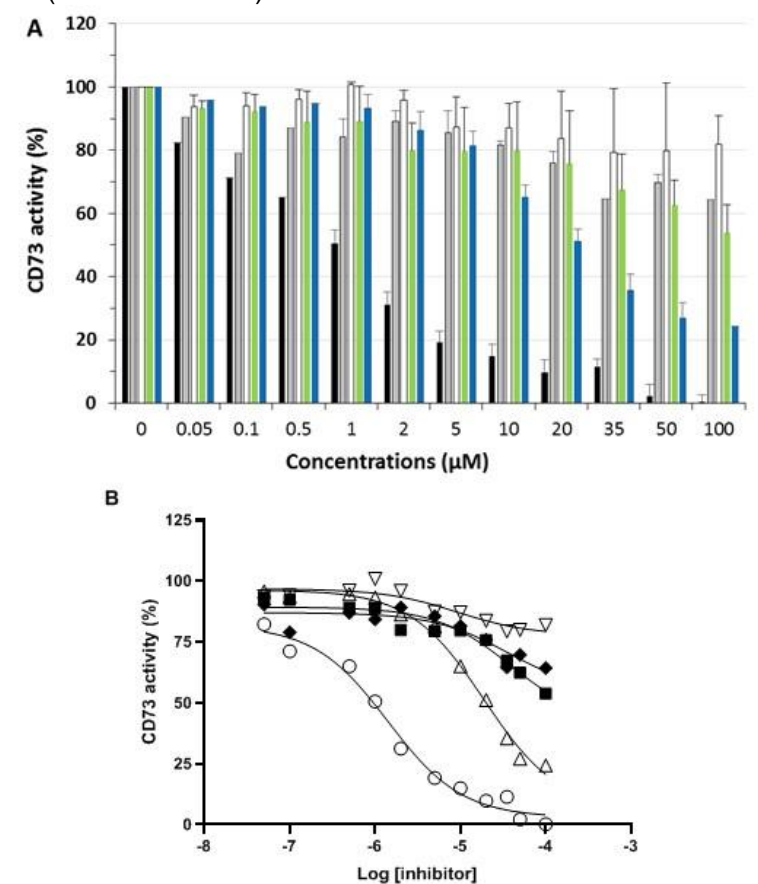

Figure 4. A) In vitro enzymatic activity measured in the presence of representative compounds: APCP (black bars), derivative 5 (grey), 6 (white), 7 (green) and 23 (blue). B) IC 50 determination for weak compounds $5(\downarrow), 6(\nabla)$, $7(\square)$, modest $23(\Delta)$ compared to strong inhibitor, APCP $(\circ)$.

For the most interesting derivative (23), a detailed inhibition curve was obtained in order to determine its $\mathrm{IC}_{50}$ values and compared to the ones of weak $(\mathbf{5}, \mathbf{6}$ and 7$)$ or strong (APCP) inhibitors (Figure 4B). For all compounds, dose response curves followed a regular sigmoidal shape even for derivatives 5-7. IC 50 was determined at $35 \pm 6 \mu \mathrm{M}$ for compound 5 , around $35 \mu \mathrm{M}$ and $92 \mu \mathrm{M}$ for compounds 6 and 7, respectively (with important incertitude for compounds 5-7 in this concentration range). In contrast, derivative 23 gave a value of $19 \pm 6 \mu \mathrm{M}$ and APCP at $1.4 \pm 1.0 \mu \mathrm{M}$. 
Table 1. Summary of biochemical properties of compounds 1-9 and 24, and reference compounds (APCP, 23 and Clofarabine PCP).

\begin{tabular}{|c|c|c|c|c|c|}
\hline Compound \# & Structure & $\begin{array}{l}\text { Docking } \\
\text { Score }^{[a]}\end{array}$ & $\begin{array}{c}\% \text { of inhibition @ } 100 \\
\mu \mathrm{M}(\% \pm \text { SEM) } \\
\text { toward purified } \\
\text { recombinant-CD73 }\end{array}$ & $\begin{array}{c}\% \text { of inhibition @ } 10 \\
\mu \mathrm{M}(\% \pm \mathrm{SEM}) \\
\text { toward purified } \\
\text { recombinant-CD73 }\end{array}$ & $\begin{array}{c}\% \text { of inhibition @ } \\
100 \mu \mathrm{M}(\% \pm \mathrm{SEM}) \\
\text { in cell based assay }\end{array}$ \\
\hline$A P C P$ & & 147.2 & $99.5 \pm 0.5$ & $81.2 \pm 6.7$ & $91 \pm 3$ \\
\hline 1 & & 106.4 & $39.4 \pm 5$ & $13.7 \pm 3$ & $12 \pm 1$ \\
\hline 2 & & 108.8 & $32.3 \pm 2.8$ & $11.9 \pm 7.4$ & $27 \pm 9$ \\
\hline 3 & & 114.3 & $19.9 \pm 3$ & $18.9 \pm 3.5$ & $44 \pm 5$ \\
\hline 4 & & 110.7 & $36 \pm 5$ & $10 \pm 8.5$ & $29 \pm 9$ \\
\hline 5 & & 118.4 & $36 \pm 6$ & $18.5 \pm 2$ & $61 \pm 8$ \\
\hline 6 & & 132 & $18 \pm 9$ & $13 \pm 8$ & n.d.a. ${ }^{[c]}$ \\
\hline 7 & & 143.7 & $46 \pm 9$ & $20.2 \pm 3$ & $45 \pm 6$ \\
\hline 8 & & 135.3 & $36.2 \pm 5$ & $5.7 \pm 4$ & $23 \pm 8$ \\
\hline 9 & & 136.6 & $51.9 \pm 2$ & $10.5 \pm 3$ & $31 \pm 7$ \\
\hline 23 & & 134.8 & $76 \pm 2.5$ & $35 \pm 4$ & $82 \pm 4$ \\
\hline 24 & & 132.5 & n.a. ${ }^{[b]}$ & n.a. ${ }^{[b]}$ & $45 \pm 9$ \\
\hline Clofarabine $P C P$ & & 142.8 & $98.5 \pm 1.5$ & $96 \pm 2.5$ & $92 \pm 4$ \\
\hline
\end{tabular}

[a] Docking score for AMP is 108.5. [b] n.a.: not active. [c] n.d.a: no data available. Data represents Mean \pm SEM of 3 independent experiments.

\section{Molecular modeling}

To understand the relatively weak and disappointing inhibition observed with most of the 5'-amino-adenosine derivatives, a molecular docking study was carried out by using the crystal structure of CD73 (4H2I). Best-ranked docking poses (according to their docking scores given by the GoldScore fitness function which takes into account $\mathrm{H}$-bonding energy, van der Waals energy, metal interaction and ligand torsion strain) were analyzed for defining the various interactions with CD73 residues arising upon binding of the compound (Figure 5). Binding orientation differed significantly for derivatives 1-4 as compared to that of APCP (Figure 5A). Indeed, two major features distinguish their binding, first the positioning of the nucleobase that is shifted and made weaker $\pi-\pi$ interactions with the two phenyl residues (F417 and F500) from CD73, and consequently the displacement of the ribose weakening its interaction with D506 (two H-bonds). Overall, the binding of such compounds altered electrostatic interactions between R354 (and R395) and 5'-oxygen and those from the a-phosphonate for APCP, as it is replaced by a single phosphonate and an amino group (preferentially $\mathrm{H}$-bond donor than $\mathrm{H}$-bond acceptor). For compound $\mathbf{5}$, the binding is strongly different to that of APCP as seen for compounds $\mathbf{1 - 4}$ and again interactions are lost between D506 and ribose hydroxyls but also with R354 and $\mathrm{N} 245$ due to the missing a-phosphonate and between $\mathrm{H} 118$ or R395 with the missing oxygen of $\beta$-phosphonate (Figure 5B). This may be explained by the length of the amino-phosphonate chain that is shorter for $\mathbf{5}$ compared to the one of APCP and since the electrostatic component is the main driving force to connect oxygen near the magnesium ion; this induces a translation of the rest of the molecule. The difference in inhibition between APCP and the potent CD73 inhibitor (23) may be explained by a weakening of electrostatic interactions between R354 and oxygen atoms (5'-oxygen, as seen by the larger distance of $5.4 \AA$ compared to $3 \AA$ with APCP) and similarly with R395 (distance increases from 2.9 to $3.3 \AA$ ). In addition to this, a slight shift of the ribose moiety is observed inducing an increase of the H-bond distance between 2'-oxygen and D506 (from 2.4 to $2.9 \AA$ ) (Figure $5 \mathrm{C}$ ). A lower activity was observed for compound 9 compared to $\mathbf{2 3}$ although these two molecules differ only by one atom at 5 ' position (nitrogen versus oxygen) and presented similar DS values. Firstly, docking analysis failed to identify important modifications between binding modes for these two compounds as they almost superimposed (Figure 6A). 


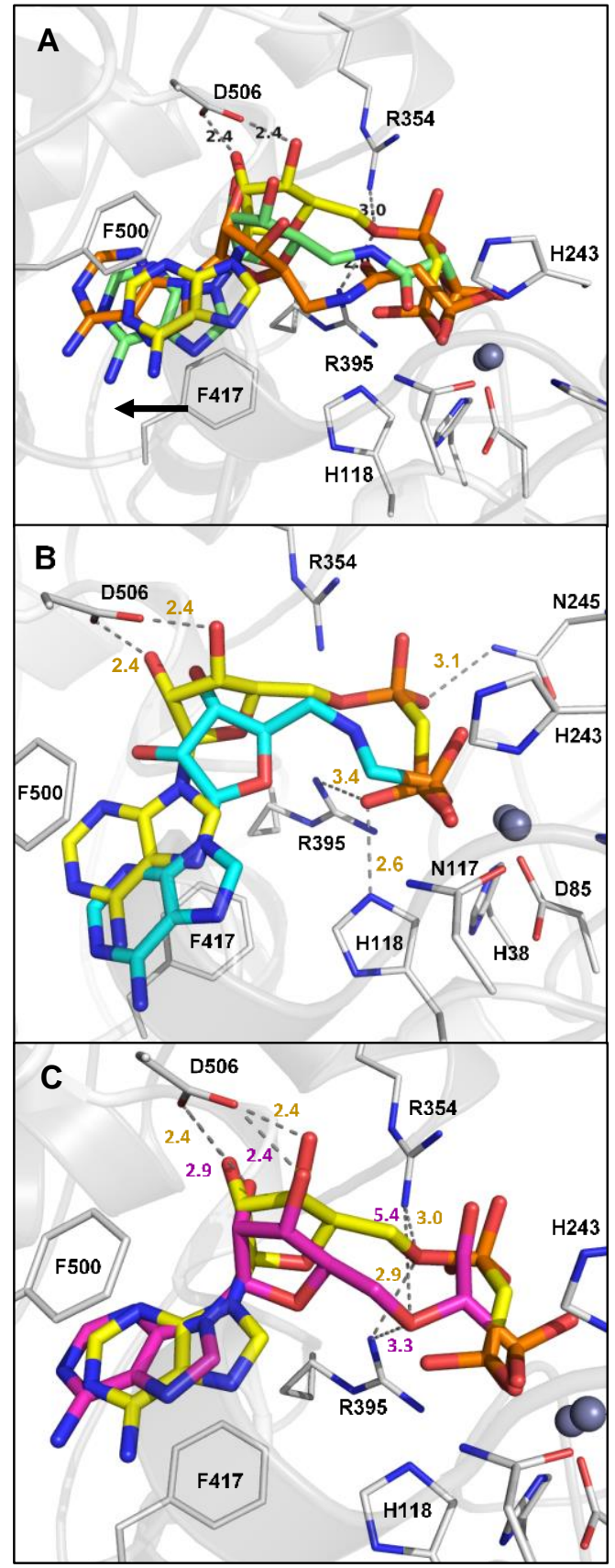

Figure 5. Binding prediction by docking for various compounds and comparison of interactions mediated with CD73 amino acids. A) Docking poses for weak inhibitors such as $\mathbf{2}$ (light green) and $\mathbf{3}$ (orange) and showing a displacement (black arrow) compared to that of APCP (depicted as yellow sticks). B) Large difference observed in binding orientation of compounds 5 (cyan) and APCP (yellow). C) Comparison between APCP (yellow) and 23 (pink sticks) highlighting changes of interaction distances between 5'-oxygen and R354/R395, and for ribose hydroxyl groups and D506.

However, a thorough analysis showed that subtle changes occurred such as the orientation of the nucleobase between both phenyl residues (possibly lowering $\pi-\pi$ interactions) and an increase of the $\mathrm{H}$-bond formed by the 2'-hydroxyl group and D506 (2.9 $\AA$ for 23 and $3.2 \AA$ for 9). Most importantly, this single atom substitution may reflect either a weakening of the interaction with R395 (stronger with an oxygen than a nitrogen because of the electronegativity) or a change / break in the $\mathrm{H}$ bond network formed between water molecules, amino acids and compound. Although five water molecules were included during the docking, no changes was observed at the vicinity of the substituted atom. This loss of activity may also be due to a change in the protonation state of $\mathrm{H} 118$ during the enzymatic reaction (achieved at $\mathrm{pH}$ 6.5) leading to a decrease in binding affinity of 9 (because of the supplementary hydrogen). Comparison of binding poses of compounds 6 and 24 (Figure $6 \mathrm{~B}$ ), and compound 24 and Clofarabine PCP (Figure 6C), highlighted the impact of both the nature of the nucleoside (adenosine or Clofarabine) and the bis(methylphosphonate) chain on the global positioning of these derivatives. These modifications have a strong impact on the orientation of the ribose moiety and consequently on the nucleobase positioning for compounds $\mathbf{6}$ and 24.

Whereas, for methylene bisphosphonate derivatives (APCP and Clofarabine PCP) modification of the nucleoside moiety did not change the final orientation of the nucleobase, as previously described ${ }^{[17]}$. In Figure $6 \mathrm{E}$, overlay of binding poses of compounds 7 and 9 show the differences of interactions between the gem-bisphosphonate (7) and $\alpha$-carboxylmethylphosphonate (9) with a slight move of the ribose weakening the interaction with D506 and R354. More notably, this binding pose suggested the loss of a major interaction between $\mathrm{N} 245$ and the third phosphate oxygen.

\section{Discussion}

We designed novel AMP or ADP analogues incorporating methyl carboxylate, methyl phosphonate, bis(methylphosphonate), gem-bisphosphonate, $\alpha$-carboxylmethylphosphonate or phosphonoacetic moieties as potential CD73 inhibitors. The replacement of the oxygen atom in the 5'-position of endogenous adenosine could allow obtaining di-substituted derivatives and may lead to additional interaction(s) in the catalytic site of the protein. First of all, the docking scores (DS) of the targeted compounds (1-9 and 24) were evaluated and compared to the ones of AMP (the natural substrate), APCP, Clofarabine PCP and compound $\mathbf{2 3}$ as reference compounds (Table 1). Most of the derivatives showed a DS higher than AMP (108.5), except the methyl carboxylate derivative (1). Based on these data, bis(methylphosphonate) (6), gem-bisphosphonate (7), and $\alpha$-carboxylmethylphosphonate (8 and 9) analogues attracted our attention as they showed DS values in the same range as APCP (147.2) and Clofarabine PCP (142.8). Compound 7, including the gem-bisphosphonate moiety, seemed to be the most promising one with a DS value of 143.7. Thus, this novel series of 5 '-aminoadenoside analogues was successfully obtained in moderate to good yields and we next investigated their ability to interfere with CD73. In all cases, replacement of the methylene bisphosphonate group of APCP lead to a decreased ability to inhibit CD73. Whereas substitution of the oxygen in 5'-position by a nitrogen atom did not seem to affect the ligand potency (DS values of 136.6 for compound 9 and 134.8 for compound $\mathbf{2 3}$ ), it significantly affects the ability to inhibit the protein. When, the adenosine moiety was replaced by Clofarabine (compounds 6 and 24), it slightly increased the potential of the inhibitors but this effect was not able to counterbalance the replacement of the nature of the hetero-atom in position 5'. Despite our effort in designing original nucleotide analogues, the replacement of the $\mathrm{P}-\mathrm{CH}_{2}-\mathrm{P}-\mathrm{O} 5$ ' pattern, and related interaction within the catalytic site of $\mathrm{CD} 73$, appears not suitable following the here proposed modifications. 


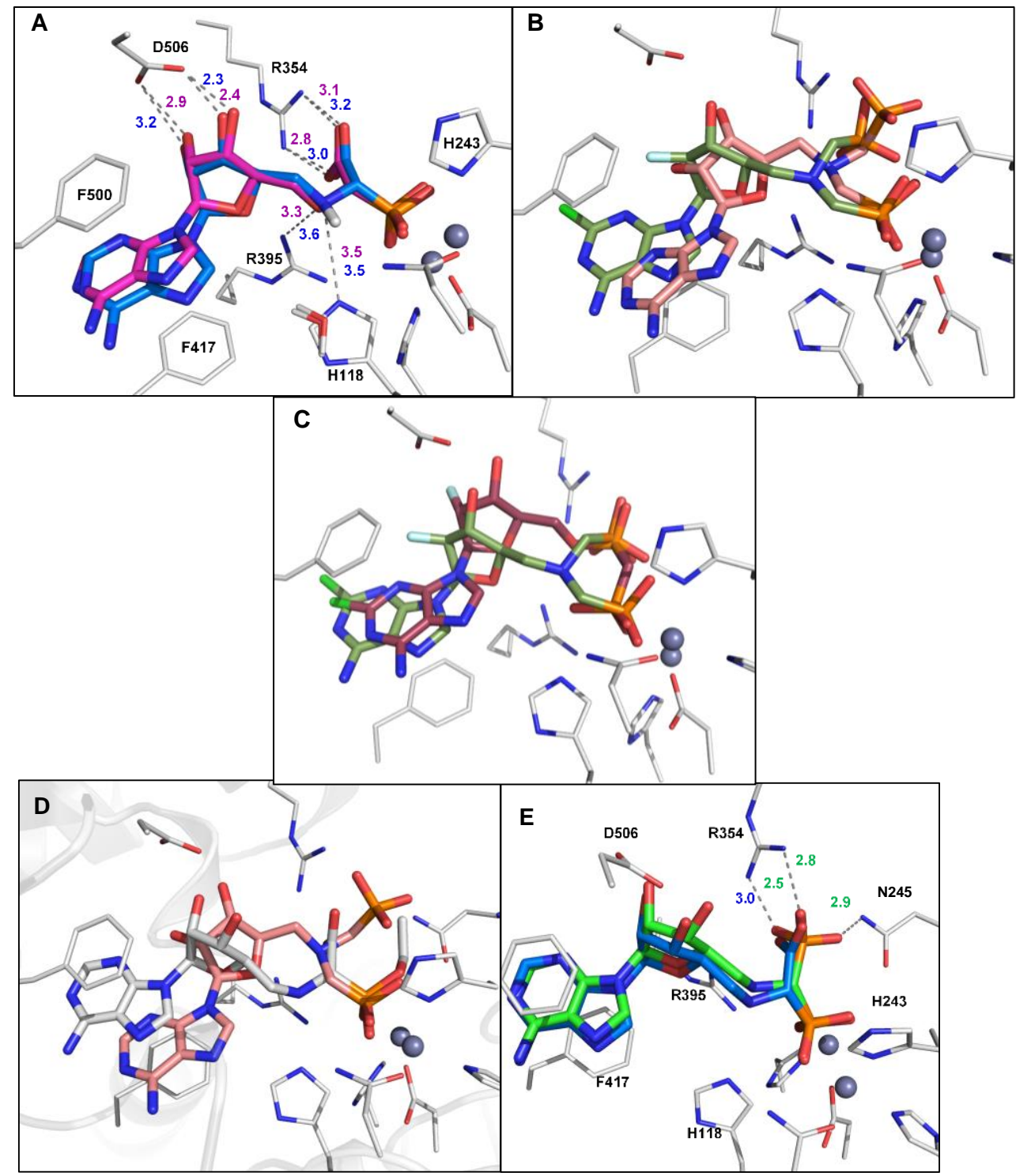

Figure 6. A) Deciphering the differential activity of compound 9 (blue) and 23 (pink sticks) by analyzing their binding mode. B) Comparison of binding mode of 6 (salmon sticks) versus 24 (dark green). C) Binding modes of 24 (dark green) and Clofarabine PCP (brown). D) Overlay of binding poses of derivatives 6 (salmon) and $\mathbf{8}$ (white). E) Binding comparison of between compounds $\mathbf{7}$ (green) and $\mathbf{9}$ (blue sticks).

According to the important contribution of the negatively charged groups over the final orientation of the inhibitor, it would be interesting to increase the distance in between the carboxylate and the phosphonate groups, and flexibility in this region may be beneficial for zinc ions chelating. In addition, as the location of carboxylate and/or phosphonate groups seems to govern the correct positioning of the nucleoside moiety, increasing this distance may lead to stronger interactions (reduction of the bonding length with D506 and hydroxyl groups and improving the $\Pi$-stacking between the nucleobase and aromatic residues).

\section{Conclusions}

Novel series of mono- or di-substituted 5'-aminonucleotide analogues including carboxylated or phosphonylated substituents, or both, were successfully obtained. All synthesized compounds were evaluated for their ability to inhibit 5'-ectonucleotidase CD73. Among them, phosphonic acids 5 and 24 showed marginal inhibition of CD73 in the cell based assay $(45-61 \%$ inhibition at $100 \mu \mathrm{M})$, as well as derivatives 7 and 9 with the purified recombinant protein (46-52\% inhibition at $100 \mu \mathrm{M})$. We assume that these differences may arise from the use of the soluble form of the protein, whereas in the cell-based assay the protein is anchored to the membrane. In these two cases, our derivatives may access and/or accommodate in a different fashion the catalytic site of the protein. In addition, molecular modeling showed that the modifications envisaged deeply impact the binding modes of the new derivatives in comparison to APCP and/or Clofarabine APCP.

Considering the literature data related to the design of nucleos(t)ide analogues as CD73 inhibitors, these results will certainly contribute to the establishment of a SAR study and further development of novel derivatives.

\section{Experimental Section}

${ }^{1} \mathrm{H}$ NMR, ${ }^{13} \mathrm{C}$ NMR and ${ }^{31} \mathrm{P}$ spectra were recorded with proton decoupling at ambient temperature on the following spectrometers: Bruker Avance III 
$(600,500$ or $400 \mathrm{MHz})$. Chemical shifts $(\delta)$ are quoted in parts per million $(\mathrm{ppm})$ referenced to the residual solvent peak chloroform $\left(\mathrm{CDCl}_{3}\right)$ at 7.26 $\mathrm{ppm}$ and $77.16 \mathrm{ppm}$, dimethyl sulfoxide (DMSO- $\mathrm{d}_{6}$ ) at $2.50 \mathrm{ppm}$ and $39.52 \mathrm{ppm}$, methanol $\left(\mathrm{CD}_{3} \mathrm{OD}\right)$ at $3.41 \mathrm{ppm}$ and $49.00 \mathrm{ppm}$, and deuterium oxide $\left(\mathrm{D}_{2} \mathrm{O}\right)$ at $4.63 \mathrm{ppm}$ relative to tetramethylsilane (TMS). For ${ }^{31} \mathrm{P}$ NMR spectra, chemical shifts are reported relative to external phosphoric acid $\left(\mathrm{H}_{3} \mathrm{PO}_{4}\right)$. COSY experiments were performed in order to confirm proton assignments as well as $2 \mathrm{D}{ }^{1} \mathrm{H}-{ }^{13} \mathrm{C}$ heteronuclear COSY for the attribution of ${ }^{13} \mathrm{C}$ signals. Coupling constants, J, are given in Hertz. Mass spectra were recorded on a Micromass Q-Tof mass spectrometer using electrospray ionization. The high-resolution mass spectra (HRMS) were obtained with a Waters Synapt G2S spectrometer equipped with positive electrospray source ionization (ESI), using Leu-enkephalin as an internal standard. The capillary voltage was set to $1.2 \mathrm{kV}$ and the sampling cone voltage was set to $30 \mathrm{~V}$. Thin layer chromatography was performed on pre-coated aluminum sheets of Silica Gel 60 F254 (Merck, Art. 5554), visualization of products was accomplished by UV absorbance followed by spraying with Hanes molybdate reagent. Column chromatography was carried out on Silica Gel 60 (Merck, Art. 9385). All moisture sensitive reactions were carried out in anhydrous conditions under argon atmosphere using oven-dried glassware. Solvents were dried and distilled prior to use and solids were dried over $\mathrm{P}_{2} \mathrm{O}_{5}$ under reduced pressure at room temperature.

General Procedure (A) for removal of acid labile sugar protecting groups. The protected derivative was dissolved in TFA- $\mathrm{H}_{2} \mathrm{O}$ (ratio 1/1, 30 $\mathrm{mL} / \mathrm{mmol}$ ) at room temperature and stirred until TLC indicated completion of the reaction. Then, the solvents were evaporated and the crude was co-evaporated with $\mathrm{EtOH}$ under reduced pressure. The crude material was purified by flash chromatography on silica gel to afford the desired product.

General Procedure (B) for diethyl phosphonate removal. The protected phosphonate (1 eq.) was dissolved in anhydrous DMF $(20 \mathrm{~mL} / \mathrm{mmol})$ and trimethylsilyl bromide (15 eq.) was added dropwise at $0^{\circ} \mathrm{C}$. The reaction mixture was stirred at room temperature until completion of the reaction was indicated by TLC $\left(\mathrm{PrOH} / \mathrm{NH}_{4} \mathrm{OH} / \mathrm{H}_{2} \mathrm{O}, 7 / 2 / 1, \mathrm{v} / \mathrm{v} / \mathrm{v}\right)$. Then, the reaction was stopped by adding triethylammonium bicarbonate buffer (TEAB $1 \mathrm{M}, \mathrm{pH}$ 7) and concentrated to dryness under high vacuum. Column chromatography of the crude materials on reverse phase (gradient: $\mathrm{H}_{2} \mathrm{O}$ to $\mathrm{MeOH} 100 \%$ ) gave the expected phosphonic acid (as triethylammonium salt), which was passed through a Dowex $\mathrm{Na}^{+}$ion exchange column, the desired fractions were collected and freeze dried leading to the title compound as sodium salt.

5'-Amino-5'-deoxy-2', 3'-O-(isopropylidene)adenosine (10) was obtained from commercially available adenosine in 3 steps with $71 \%$ overall yield according to previously published procedures. [9] Characterizations $\left({ }^{1} \mathrm{H},{ }^{13} \mathrm{C}\right.$ and $\left.\mathrm{MS}\right)$ were in agreement with the literature. $\mathrm{R}_{\mathrm{f}}\left(\mathrm{CH}_{2} \mathrm{Cl}_{2} / \mathrm{MeOH}\right.$ 9/1) 0.04. ${ }^{1} \mathrm{H}$ NMR $\left(300 \mathrm{MHz}, \mathrm{CDCl}_{3}\right): \delta 8.31(\mathrm{~s}, 1 \mathrm{H}, \mathrm{H}-$ 2), $7.91(\mathrm{~s}, 1 \mathrm{H}, \mathrm{H}-8), 6.11\left(\mathrm{~s}, 2 \mathrm{H}, \mathrm{NH}_{2}\right), 6.02\left(\mathrm{~d}, J=3.0 \mathrm{~Hz}, 1 \mathrm{H}, \mathrm{H}^{\prime}{ }^{\prime}\right)$, 5.46 (dd, $\left.J=6.5,3.0 \mathrm{~Hz}, 1 \mathrm{H}, \mathrm{H}-2^{\prime}\right), 5.01$ (dd, $J=6.5,3.5 \mathrm{~Hz}, 1 \mathrm{H}, \mathrm{H}-3^{\prime}$ ), 4.24 (dd, $J=9.3,4.5 \mathrm{~Hz}, 1 \mathrm{H}, \mathrm{H}-4^{\prime}$ ), 2.99 (qd, $J=13.4,5.2 \mathrm{~Hz}, 2 \mathrm{H}, \mathrm{H}^{-} 5^{\prime}$ ), $1.72\left(\mathrm{~s}, 2 \mathrm{H}, \mathrm{CH}_{2}-\mathrm{NH}_{2}\right), 1.60\left(\mathrm{~s}, 3 \mathrm{H}, \mathrm{CH}_{3}\right), 1.37\left(\mathrm{~s}, 3 \mathrm{H}, \mathrm{CH}_{3}\right) .{ }^{13} \mathrm{C} \mathrm{NMR}(75$ $\mathrm{MHz}, \mathrm{CDCl}_{3}$ ): $\delta 155.9$ (C-6), 153.3 (C-2), 149.5 (C-4), 140.0 (C-8), 120.5

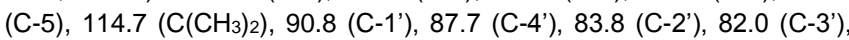
44.0 (C-5), $27.4\left(\mathrm{CH}_{3}\right), 25.5\left(\mathrm{CH}_{3}\right)$. Q-TOF MS E+: m/z $307.15(\mathrm{M}+\mathrm{H})^{+}$. HRMS Q-TOF MS E+: Calculated for $\mathrm{C}_{13} \mathrm{H}_{19} \mathrm{~N}_{6} \mathrm{O}_{3}[\mathrm{M}+\mathrm{H}]^{+} 307.1519$; found 307.1521.

5'-N-acetate-5'-deoxyadenosine (1) To a suspension of compound 10 $(535 \mathrm{mg}, 1.61 \mathrm{mmol})$ in anhydrous $\mathrm{MeOH}(32 \mathrm{~mL})$ and under argon atmosphere was added freshly distilled triethylamine $(566 \mu \mathrm{L}, 2.5$ eq.). Methyl bromoacetate (312 $\mu \mathrm{L}, 2.05 \mathrm{eq}$.) was then dropwise added over a period of $2 \mathrm{~h}$ and the reaction mixture was refluxed overnight before concentration under reduced pressure. Purification by flash chromatography on silica gel $\left(\mathrm{CH}_{2} \mathrm{Cl}_{2} / \mathrm{MeOH}, 19 / 1\right.$ to $\left.9 / 1\right)$ afforded the alkylated intermediate as white solid $(705 \mathrm{mg}$ containing $20 \%$ of triethylammonium salts). This last was directly used in the next step without further purification. $\mathrm{R}_{\mathrm{f}}\left(\mathrm{CH}_{2} \mathrm{Cl}_{2} / \mathrm{MeOH}\right.$ 9/1) 0.41. Q-TOF MS E+: $\mathrm{m} / \mathrm{z} 379.17(\mathrm{M}+\mathrm{H})^{+}$. HRMS Q-TOF MS E+: Calculated for $\mathrm{C}_{16} \mathrm{H}_{23} \mathrm{~N}_{6} \mathrm{O}_{5}$ $\left([\mathrm{M}+\mathrm{H}]^{+}\right.$379.1730; found: 379.1728 . This derivative $(200 \mathrm{mg}, 0.44 \mathrm{mmol})$ was treated following general procedure A. Purification was achieved by flash chromatography on silica gel (EtOAc/ $\mathrm{MeOH}, 100 / 0$ to $50 / 50)$ to give the deprotected intermediate (as a white solid, $246 \mathrm{mg}, 45 \%$ for two steps) which was engaged in the saponification step. $\mathrm{R}_{\mathrm{f}}(\mathrm{EtOAc} / \mathrm{MeOH}$ 1/4) 0.40. Q-TOF MS E+: m/z 339.14 (M+H)+. Q-TOF MS E: $\mathrm{m} / \mathrm{z} 337.10$ $(\mathrm{M}-\mathrm{H})^{\text {. }}$. HRMS Q-TOF MS E+: Calculated for $\mathrm{C}_{13} \mathrm{H}_{19} \mathrm{~N}_{6} \mathrm{O}_{5}[\mathrm{M}+\mathrm{H}]^{+}$ 339.1417; found: 339.1418 . UV (EtOH abs) $\lambda \max =259 \mathrm{~nm}\left(\varepsilon_{\max }=9710\right)$. Thus, methyl ester derivative $(194 \mathrm{mg}, 0.58 \mathrm{mmol})$ was dissolved in $\mathrm{NaOH} 1 \mathrm{M}$ solution and stirred at room temperature for $2 \mathrm{~h}$. The volatiles were removed under reduced pressure and the crude was purified by flash chromatography on silica gel (EtOAc/MeOH, 1/2 to 0/100) to afford compound 1 as a white solid (118 mg, 60\%). $\mathrm{Rf}(\mathrm{EtOAc/MeOH} 1 / 9) 0.05$. ${ }^{1} \mathrm{H}$ NMR $\left(600 \mathrm{MHz}, \mathrm{D}_{2} \mathrm{O}\right): \delta 8.31$ (s, $\left.1 \mathrm{H}, \mathrm{H}-2\right), 8.20(\mathrm{~s}, 1 \mathrm{H}, \mathrm{H}-8), 6.08(\mathrm{~d}, J$ $\left.=5.5 \mathrm{~Hz}, 1 \mathrm{H}, \mathrm{H}-1^{\prime}\right), \mathrm{H}-2^{\prime}$ (signal in $\mathrm{D}_{2} \mathrm{O}$ peak), $4.39-4.35\left(\mathrm{~m}, 2 \mathrm{H}, \mathrm{H}-3^{\prime}\right.$, $\left.\mathrm{H}-4^{\prime}\right), 3.45-3.38\left(\mathrm{~m}, 2 \mathrm{H}, \mathrm{CH}_{2}-\mathrm{CO}\right), 3.17$ (d, $\left.J=5.6 \mathrm{~Hz}, 2 \mathrm{H}, \mathrm{H}-5^{\prime}\right) .{ }^{13} \mathrm{C}$ NMR (151 MHz, D 20$): \delta 176.5(\mathrm{C}=\mathrm{O}), 155.5(\mathrm{C}-6), 152.8(\mathrm{C}-2), 148.7$ (C-4), 140.3 (C-8), 118.9 (C-5), 88.1 (C-1'), 82.2 (C-4'), 73.5 (C-2'), 71.5 (C-3'), $51.3\left(\mathrm{CH}_{2}-\mathrm{CO}\right), 49.9\left(\mathrm{C}-5^{\prime}\right)$. Q-TOF MS E+: m/z $347.11(\mathrm{M}+\mathrm{H})^{+}$. HRMS Q-TOF MS E+: Calculated for $\mathrm{C}_{12} \mathrm{H}_{17} \mathrm{~N}_{6} \mathrm{O}_{5}[\mathrm{M}-\mathrm{Na}+2 \mathrm{H}]^{+} 325.1260$; found: 325.1261

\section{5'-Deoxy-5'- $N$-[(diethyl-phosphono)acetyl]-2', 3'-O-isopropylidene-} adenosine (11) ${ }^{[12]}$ Diethyl phosphonoacetic acid (321 $\mu \mathrm{L}$, 2 eq.) was slowly added, at room temperature and under an argon atmosphere, to a solution of compound 10 (306 mg, $1 \mathrm{mmol})$, DCC (495 mg, 2.4 eq.) and 4-DMAP (12 mg, 0.1 eq.) in anhydrous DMF (12 ml). After $20 \mathrm{~h}$, the reaction mixture was filtered and the filtrate was evaporated under reduced pressure. The resulting oil was then co-evaporated 3 times with $\mathrm{EtOH}\left(10 \mathrm{~mL}\right.$ ) before dissolution with $\mathrm{CH}_{2} \mathrm{Cl}_{2}$. The organic layer was washed with $\mathrm{H}_{2} \mathrm{O}$ (twice), dried $\left(\mathrm{MgSO}_{4}\right)$, filtered and concentrated to dryness. The resulting oil was purified by silica gel column chromatography $\left(\mathrm{CH}_{2} \mathrm{Cl}_{2} / \mathrm{MeOH}, 9 / 1\right)$ to give compound $\mathbf{1 1}$ as a yellow foam $(233 \mathrm{mg}, 72 \%)$. $\mathrm{R}_{\mathrm{f}}\left(\mathrm{CH}_{2} \mathrm{Cl}_{2} / \mathrm{MeOH} 9 / 1\right)$ 0.33. ${ }^{1} \mathrm{H} \mathrm{NMR}(300 \mathrm{MHz}$, $\left.\mathrm{CDCl}_{3}\right): \delta 8.39$ (brs, $\left.1 \mathrm{H}, \mathrm{NH}\right), 8.37(\mathrm{~s}, 1 \mathrm{H}, \mathrm{H}-2), 7.93(\mathrm{~s}, 1 \mathrm{H}, \mathrm{H}-8), 6.00$ (brs, $2 \mathrm{H}, \mathrm{NH}_{2}$ ), 5.87 (d, $J=4.5 \mathrm{~Hz}, 1 \mathrm{H}, \mathrm{H}-1^{\prime}$ ), 5.37 (dd, $J=6.2,4.5 \mathrm{~Hz}$ $\left.1 \mathrm{H}, \mathrm{H}^{\prime} \mathbf{2}^{\prime}\right), 4.86\left(\mathrm{dd}, J=6.3,2.3 \mathrm{~Hz}, 1 \mathrm{H}, \mathrm{H}-3^{\prime}\right), 4.46(\mathrm{dd}, J=5.9,3.3 \mathrm{~Hz}$, $\left.1 \mathrm{H}, \mathrm{H}-4^{\prime}\right), 4.20-4.01\left(\mathrm{~m}, 5 \mathrm{H}, \mathrm{O}-\mathrm{CH}_{2}\right.$ and $\left.\mathrm{H}^{\prime} 5^{\prime}\right), 3.38-3.33\left(\mathrm{~m}, 1 \mathrm{H}, \mathrm{H}-5^{\prime}\right)$, 2.97 (dd, $\left.J=21.4,4.7 \mathrm{~Hz}, 2 \mathrm{H}, \mathrm{CH}_{2}-\mathrm{P}\right), 1.60\left(\mathrm{~s}, 3 \mathrm{H}, \mathrm{CH}_{3}\right), 1.35(\mathrm{~s}, 3 \mathrm{H}$, $\left.\mathrm{CH}_{3}\right), 1.33-1.27\left(\mathrm{~m}, 6 \mathrm{H}, \mathrm{O}-\mathrm{CH}_{2}-\mathrm{CH}_{3}\right) .{ }^{13} \mathrm{C}$ NMR $\left(75 \mathrm{MHz}, \mathrm{CDCl}_{3}\right): \delta$ $165.4(\mathrm{~d}, J=4.9 \mathrm{~Hz}, \mathrm{C}=\mathrm{O}), 155.8$ (C-6), 152.8 (C-2), 148.7 (C-4), 140.3 (C-8), 119.8 (C-5), $114.9\left(\underline{\mathrm{C}}\left(\mathrm{CH}_{3}\right)_{2}\right), 91.1$ (C-1'), 83.8 (C-4'), 82.9 (C-2'), 81.5 (C-3'), 63.1 (d, $\left.J=11.2 \mathrm{~Hz}, \mathrm{O}-\mathrm{CH}_{2}-\mathrm{CH}_{3}\right), 41.2\left(\mathrm{C}-5^{\prime}\right), 35.2$ (d, $J=$ $\left.134.1 \mathrm{~Hz}, \mathrm{CH}_{2}-\mathrm{P}\right), 27.0\left(\mathrm{C}\left(\underline{\mathrm{CH}}_{3}\right)_{2}\right), 25.0\left(\mathrm{C}\left(\underline{\mathrm{CH}}_{3}\right)_{2}\right), 15.98(\mathrm{~d}, J=6.1 \mathrm{~Hz}$, $\left.\mathrm{O}-\mathrm{CH}_{2}-\mathrm{CH}_{3}\right) .{ }^{31} \mathrm{P}$ NMR (121 MHz, $\left.\mathrm{CDCl}_{3}\right): \delta$ 22.1. Q-TOF MS E': $\mathrm{m} / \mathrm{z}$ $485.19(\mathrm{M}+\mathrm{H})^{+}$. HRMS Q-TOF MS $\mathrm{E}^{+}$: Calculated for $\mathrm{C}_{19} \mathrm{H}_{29} \mathrm{~N}_{6} \mathrm{O}_{7} \mathrm{P}$ $[\mathrm{M}+\mathrm{H}]^{+}$485.1914; found: 485.1923 .

5'-Deoxy-5'-N-[(diethyl-phosphono)acetyl]adenosine (12 ${ }^{[12]}$ The title compound was obtained as a white solid $(350 \mathrm{mg}, 90 \%$ ) from compound $11(424 \mathrm{mg}, 0.876 \mathrm{mmol}$ ) using general procedure A. Purification was achieved by flash chromatography on silica gel $\left(\mathrm{CH}_{2} \mathrm{Cl}_{2} / \mathrm{MeOH}, 9 / 1\right.$. $\mathrm{R}_{f}$ $\left(\mathrm{CH}_{2} \mathrm{Cl}_{2} / \mathrm{MeOH}\right.$ 9/1) 0.08. ${ }^{1} \mathrm{H}$ NMR (300 MHz, DMSO-d6): $\delta 8.39$ (s, $1 \mathrm{H}$, $\mathrm{H}-2$ ), 8.19 (s, $1 \mathrm{H}, \mathrm{H}-8), 7.40$ (brs, $2 \mathrm{H}, \mathrm{NH}_{2}$ ), 5.86 (d, $J=6.3 \mathrm{~Hz}, 1 \mathrm{H}, \mathrm{H}-1^{\prime}$ ), $5.43(\mathrm{brs}, 1 \mathrm{H}, \mathrm{OH}), 5.28(\mathrm{brs}, 1 \mathrm{H}, \mathrm{OH}), 4.68\left(\mathrm{t}, J=5.7 \mathrm{~Hz} 1 \mathrm{H}, \mathrm{H}-2^{\prime}\right), 4.07$ - $3.93\left(\mathrm{~m}, 6 \mathrm{H}, \mathrm{H}-3^{\prime}, \mathrm{H}-4^{\prime}\right.$ and $\mathrm{O}-\mathrm{CH}_{2}-\mathrm{CH}_{3}$ ), $\mathrm{H}-5^{\prime}$ ( signal in $\mathrm{H}_{2} \mathrm{O}$ peak.) $2.91\left(\mathrm{~d}, J=21.4 \mathrm{~Hz}, 2 \mathrm{H}, \mathrm{CH}_{2}-\mathrm{P}\right), 1.21\left(\mathrm{t}, J=7.1 \mathrm{~Hz}, 6 \mathrm{H}, \mathrm{CH}_{3}\right) .{ }^{13} \mathrm{C} \mathrm{NMR}$ (75 MHz, DMSO-d6): $\delta 164.3$ (C=O), 156.0 (C-6), 152.3 (C-2), 149.3 (C4), 140.4 (C-8), 119.4 (C-5), 87.6 (C-1'), 83.5 (C-4'), 72.7 (C-2'), 71.1 (C3'), $61.7\left(\mathrm{~d}, J=6.1 \mathrm{~Hz}, \mathrm{O}-\mathrm{CH}_{2}-\mathrm{CH}_{3}\right), 41.3\left(\mathrm{C}-5^{\prime}\right), 34.6(\mathrm{~d}, J=132.3 \mathrm{~Hz}$, $\left.\mathrm{CH}_{2}-\mathrm{P}\right), 16.2\left(\mathrm{~d}, J=5.8 \mathrm{~Hz}, \mathrm{CH}_{3}\right) .{ }^{31} \mathrm{P}$ NMR (121 MHz, DMSO-d6): $\delta 22.8$. Q-TOF MS E+: $\mathrm{m} / \mathrm{z} 445.16(\mathrm{M}+\mathrm{H})^{+}$.

5'-Deoxy-5'- $N$-(phosphono-acetyl)adenosine (disodium salts) (2) ${ }^{[12]}$ The title compound was obtained as a white solid (17 $\mathrm{mg}, 7 \%)$ from 
compound 12 (287 mg, $0.646 \mathrm{mmol}$ ) using general procedure $B$. Purification was achieved by flash chromatography on reverse phase $\left(\mathrm{H}_{2} \mathrm{O} / \mathrm{MeOH}, 100 / 0\right.$ to $\left.50 / 50\right)$. $\mathrm{R}_{\mathrm{f}}\left(\mathrm{PrOH} / \mathrm{H}_{2} \mathrm{O} / \mathrm{NH}_{4} \mathrm{OH}, 6 / 3 / 1\right) \quad 0.39$. ${ }^{1} \mathrm{H}$ NMR (400 MHz, $\left.\mathrm{D}_{2} \mathrm{O}\right): \delta 8.31(\mathrm{~s}, 1 \mathrm{H}, \mathrm{H}-2), 8.19(\mathrm{~s}, 1 \mathrm{H}, \mathrm{H}-8), 6.01$ (d, $J=$ $\left.5.6 \mathrm{~Hz}, 1 \mathrm{H}, \mathrm{H}-1^{\prime}\right), \mathrm{H}-2^{\prime}$ signal in $\mathrm{D}_{2} \mathrm{O}$ peak, $4.35\left(\mathrm{t}, J=4.8 \mathrm{~Hz}, 1 \mathrm{H}, \mathrm{H}-2^{\prime}\right)$, 4.28 (q, $J=4.8 \mathrm{~Hz}, 1 \mathrm{H}, \mathrm{H}-4$ '), 3.65 and 3.56 (ABX, $J=14.5,5.3,4.8 \mathrm{~Hz}$, $\left.2 \mathrm{H}, \mathrm{H}-5^{\prime}\right), 2.62\left(\mathrm{~d}, J=19.2 \mathrm{~Hz}, 2 \mathrm{H}, \mathrm{CH}_{2}-\mathrm{P}\right) .{ }^{13} \mathrm{C}$ NMR $\left(101 \mathrm{MHz}, \mathrm{D}_{2} \mathrm{O}\right): \delta$ 172.4 (d, $J=4.4 \mathrm{~Hz}, \mathrm{C}=\mathrm{O}$ ), 155.4 (C-6), 152.7 (C-2), 148.7 (C-4), 140.2 (C-8), 118.8 (C-5), 87.4 (C-1'), 83.2 (C-4'), 73.2 (C-2'), 70.9 (C-3'), 40.9 (C-5'), 38.4 (d, $\left.J=115.1 \mathrm{~Hz}, \mathrm{CH}_{2}-\mathrm{P}\right)$. ${ }^{31} \mathrm{P}$ NMR $\left(162 \mathrm{MHz}, \mathrm{D}_{2} \mathrm{O}\right): \delta 12.45$. Q-TOF MS E+: $\mathrm{m} / \mathrm{z} 389.10(\mathrm{M}+\mathrm{H})^{+}$. HRMS Q-TOF MS $\mathrm{E}^{+}$: for Calculated $\mathrm{C}_{12} \mathrm{H}_{18} \mathrm{~N}_{6} \mathrm{O}_{7} \mathrm{P}[\mathrm{M}+\mathrm{H}]^{+} 389.0975$; found: 389.0975. UV (EtOH abs) $\lambda \max =$ $261 \mathrm{~nm}(\varepsilon \max =12300)$.

5'-Deoxy-5'-N-(ethyl-phosphono-acetyl)adenosine (monosodium salt) (3) Compound 3 was obtained as a white solid (60 mg, 20\%) from compound 12 (350 mg, $0.790 \mathrm{mmol}$ ) using general procedure B. Purification was achieved by flash chromatography on reverse phase $\left(\mathrm{H}_{2} \mathrm{O} / \mathrm{MeOH}, 100 / 0\right.$ to $\left.50 / 50\right)$. $\mathrm{R}_{\mathrm{f}}\left(\mathrm{iPrOH} / \mathrm{H}_{2} \mathrm{O} / \mathrm{NH}_{4} \mathrm{OH}, 6 / 3 / 1\right) 0.59 .{ }^{1} \mathrm{H}$ $\operatorname{NMR}\left(400 \mathrm{MHz}, \mathrm{D}_{2} \mathrm{O}\right): \delta 8.31(\mathrm{~s}, 1 \mathrm{H}, \mathrm{H}-2), 8.25(\mathrm{~s}, 1 \mathrm{H}, \mathrm{H}-8), 6.01(\mathrm{~d}, J=$ $\left.5.6 \mathrm{~Hz}, 1 \mathrm{H}, \mathrm{H}-1^{\prime}\right), 4.84-4.81\left(\mathrm{~m}, 1 \mathrm{H}, \mathrm{H}-2^{\prime}\right), 4.35-4.26\left(\mathrm{~m}, 2 \mathrm{H}, \mathrm{H}-3^{\prime}\right.$ and $\mathrm{H}-4$ '), $3.92-3.83\left(\mathrm{~m}, 2 \mathrm{H}, \mathrm{O}-\mathrm{CH}_{2}-\mathrm{CH}_{3}\right), 3.70$ and 3.51 ( $\mathrm{ABX}, J=15.5,5.2$ $\left.3.7 \mathrm{~Hz}, 2 \mathrm{H}, \mathrm{H}-5^{\prime}\right), 2.72\left(\mathrm{~d}, J=20.3 \mathrm{~Hz}, 2 \mathrm{H}, \mathrm{CH}_{2}-\mathrm{P}\right), 1.15(\mathrm{t}, J=7.1 \mathrm{~Hz}$, $\left.3 \mathrm{H}, \mathrm{CH}_{3}\right) .{ }^{13} \mathrm{C}$ NMR $\left(101 \mathrm{MHz}, \mathrm{D}_{2} \mathrm{O}\right): \delta 170.3(\mathrm{~d}, J=5.7 \mathrm{~Hz}, \mathrm{C}=\mathrm{O}), 155.6$ (C-6), 152.9 (C-2), 148.8 (C-4), 140.5 (C-8), 119.0 (C-5), 87.7 (C-1'), 83.3 (C-4'), 73.1 (C-2'), 70.9 (C-3'), 61.3 (d, J = $5.9 \mathrm{~Hz}, \mathrm{O}-\mathrm{CH}_{2}-\mathrm{CH}_{3}$ ), 40.9 (C-5'), 36.4 (d, $J=122.0 \mathrm{~Hz}, \mathrm{CH}_{2}-\mathrm{P}$ ), 15.83 (d, $J=6.2 \mathrm{~Hz}, \mathrm{CH}_{3}$ ). ${ }^{31} \mathrm{P}$ NMR (162 MHz, D $2 \mathrm{O}$ ): $\delta$ 16.0. Q-TOF MS E+: m/z $439.11(\mathrm{M}+\mathrm{H})^{+}$. Q-TOF MS E*: m/z 415.11 (M-Na). HRMS Q-TOF MS E+: Calculated for $\mathrm{C}_{14} \mathrm{H}_{21} \mathrm{~N}_{6} \mathrm{O}_{7} \mathrm{NaP}[\mathrm{M}+\mathrm{H}]^{+}$439.1107; found: 439.1108. UV (EtOH abs) $\lambda \max =259 \mathrm{~nm}(\varepsilon \max =13900)$.

\section{5'-Deoxy-5'-N-[(diethyl-phosphono)methyl]-2', 3'-O-isopropylidene-} adenosine (13) A solution of compound $10(408 \mathrm{mg}, 1.2 \mathrm{mmol})$ in anhydrous THF $(4 \mathrm{~mL})$ was added, at room temperature, to a mixture of (diethoxyphosphoryl)methyl 4-methylbenzenesulfonate (322 mg, 1.0 $\mathrm{mmol})$ and DBU $(152 \mu \mathrm{l}, 1.0 \mathrm{mmol})$ under an argon atmosphere. The reaction mixture was stirred at $50^{\circ} \mathrm{C}$ for 4 days before concentration under reduced pressure. The crude was purified by flash chromatography on silica gel $\left(\mathrm{CH}_{2} \mathrm{Cl}_{2} / \mathrm{MeOH}, 9 / 1\right)$ to give 13 as a white solid $(232 \mathrm{mg}, 51 \%)$. $\mathrm{R}_{\mathrm{f}}\left(\mathrm{CH}_{2} \mathrm{Cl}_{2} / \mathrm{MeOH} 9 / 1\right)$ 0.40. ${ }^{1} \mathrm{H} \mathrm{NMR}(400 \mathrm{MHz}$, $\left.\mathrm{CDCl}_{3}\right): \delta 8.35(\mathrm{~s}, 1 \mathrm{H}, \mathrm{H}-2), 7.92(\mathrm{~s}, 1 \mathrm{H}, \mathrm{H}-8), 6.00(\mathrm{~d}, J=3.0 \mathrm{~Hz}, 1 \mathrm{H}, \mathrm{H}-$ 1'), $5.77\left(\mathrm{~s}, 2 \mathrm{H}, \mathrm{NH}_{2}\right.$ ), $5.42(\mathrm{dd}, J=6.3,3.1 \mathrm{~Hz}, 1 \mathrm{H}, \mathrm{H}-2$ '), $5.02(\mathrm{dd}, J=$ 6.3, 3.3 Hz, 1H, H-3'), $4.35-4.33\left(\mathrm{~m}, 1 \mathrm{H}, \mathrm{H}-4^{\prime}\right), 4.16-4.07$ (m, 4H, O$\left.\mathrm{CH}_{2}-\mathrm{CH}_{3}\right), 3.07-2.93\left(\mathrm{~m}, 4 \mathrm{H}, \mathrm{H}-5^{\prime}+\mathrm{CH}_{2}-\mathrm{P}\right), 1.60$ (s, 3H, $\left.\mathrm{CH}_{3}\right), 1.37$ (s, $\left.3 \mathrm{H}, \mathrm{CH}_{3}\right), 1.35-1.27\left(\mathrm{~m}, 6 \mathrm{H}, \mathrm{O}-\mathrm{CH}_{2}-\mathrm{CH}_{3}\right) \cdot{ }^{13} \mathrm{C} \mathrm{NMR}\left(101 \mathrm{MHz}, \mathrm{CDCl}_{3}\right)$ : ठ 155.7 (C-6), 153.4 (C-2), 149.6 (C-4), 140.0 (C-8), 120.5 (C-5), 114.7 $\left(\mathrm{C}\left(\mathrm{CH}_{3}\right)_{2}\right), 90.9\left(\mathrm{C}-1^{\prime}\right), 85.6$ (C-4'), 83.6 (C-2'), $82.3\left(\mathrm{C}-3^{\prime}\right), 62.2(\mathrm{~d}, \mathrm{~J}=$ $\left.6.6 \mathrm{~Hz}, \mathrm{O}-\mathrm{CH}_{2}-\mathrm{CH}_{3}\right), 52.5\left(\mathrm{~d}, \mathrm{~J}=13.0 \mathrm{~Hz}, \mathrm{C}-5^{\prime}\right), 45.3(\mathrm{~d}, J=154.5 \mathrm{~Hz}$, $\left.\mathrm{CH}_{2}-\mathrm{P}\right), 27.4\left(\mathrm{CH}_{3}\right), 25.5\left(\mathrm{CH}_{3}\right), 16.6\left(\mathrm{~d}, J=5.7 \mathrm{~Hz}, \mathrm{O}-\mathrm{CH}_{2}-\mathrm{CH}_{3}\right) .{ }^{31} \mathrm{P}$ NMR (162 MHz, $\left.\mathrm{CDCl}_{3}\right): \delta$ 25.7. Q-TOF MS E+: $\mathrm{m} / \mathrm{z} 457.20(\mathrm{M}+\mathrm{H})^{+}$. HRMS Q-TOF MS E+: Calculated for $\mathrm{C}_{18} \mathrm{H}_{30} \mathrm{~N}_{6} \mathrm{O}_{6} \mathrm{P}[\mathrm{M}+\mathrm{H}]^{+}$457.1964; found: 457.1965 .

5'-Deoxy-5'-N-[(diethyl-phosphono)methyl]adenosine (14) The title compound was obtained as a white solid $(60 \mathrm{mg}, 33 \%)$ from compound $13(200 \mathrm{mg}, 0.438 \mathrm{mmol})$ using general procedure A. Purification was achieved by flash chromatography on reverse phase $\left(\mathrm{H}_{2} \mathrm{O} / \mathrm{MeOH}, 100 / 0\right.$ to $50 / 50)$. $\mathrm{Rf}\left(\mathrm{CH}_{2} \mathrm{Cl}_{2} / \mathrm{MeOH}\right.$ 9/1) 0.06. ${ }^{1} \mathrm{H}$ NMR $\left(300 \mathrm{MHz}, \mathrm{D}_{2} \mathrm{O}\right): \delta 8.27$ (s $1 \mathrm{H}, \mathrm{H}-2), 8.25(\mathrm{~s}, 1 \mathrm{H}, \mathrm{H}-8), 6.07\left(\mathrm{~d}, J=5.4 \mathrm{~Hz}, 1 \mathrm{H}, \mathrm{H}-1^{\prime}\right), 4.86-4.82(\mathrm{~m}$ $\left.1 \mathrm{H}, \mathrm{H}-2^{\prime}\right), 4.47-4.41$ ( $\mathrm{m}, 2 \mathrm{H}, \mathrm{H}-3^{\prime}$ and $\left.\mathrm{H}-4^{\prime}\right), 4.19-4.06\left(\mathrm{~m}, 4 \mathrm{H}, \mathrm{O}-\mathrm{CH}_{2}\right.$ $\left.\mathrm{CH}_{3}\right), 3.55\left(\mathrm{~d}, J=13.5 \mathrm{~Hz}, 2 \mathrm{H}, \mathrm{H}-5^{\prime}\right), 3.49\left(\mathrm{~d}, J=5.8 \mathrm{~Hz}, 2 \mathrm{H}, \mathrm{CH}_{2}-\mathrm{P}\right)$, $1.23\left(\mathrm{t}, J=6.9 \mathrm{~Hz}, 3 \mathrm{H}, \mathrm{CH}_{3}\right), 1.19\left(\mathrm{t}, J=6.8 \mathrm{~Hz}, 3 \mathrm{H}, \mathrm{CH}_{3}\right) .{ }^{13} \mathrm{C} \mathrm{NMR}(75$ $\mathrm{MHz}, \mathrm{D}_{2} \mathrm{O}$ ): $\delta 155.3$ (C-6), 152.3 (C-2), 148.4 (C-4), 141.0 (C-8), 119.3 (C-5), 89.2 (C-1'), 80.1 (C-4'), 73.0 (C-2'), 71.6 (C-3'), 64.6 (d, J=6.5 Hz, $\left.\mathrm{O}-\mathrm{CH}_{2}-\mathrm{CH}_{3}\right), 50.3\left(\mathrm{~d}, J=9.6 \mathrm{~Hz}, \mathrm{C}-5^{\prime}\right), 41.2\left(\mathrm{~d}, J=153.1 \mathrm{~Hz}, \mathrm{CH}_{2}-\mathrm{P}\right)$, $15.5-15.3\left(\mathrm{~m}, \mathrm{CH}_{3}\right) .{ }^{31} \mathrm{P}$ NMR $\left(121 \mathrm{MHz}, \mathrm{D}_{2} \mathrm{O}\right): \delta$ 20.6. Q-TOF MS E': $\mathrm{m} / \mathrm{z}$ 417.17 $(\mathrm{M}+\mathrm{H})^{+}$. HRMS Q-TOF MS E+: Calculated for $\mathrm{C}_{15} \mathrm{H}_{26} \mathrm{~N}_{6} \mathrm{O}_{6} \mathrm{P}$ $[\mathrm{M}+\mathrm{H}]^{+}$417.1651; found: 417.1651 .

5'-Deoxy-5'-N-[(ethyl-phosphono)methyl]adenosine (monosodium salt) (4) The title compound was obtained as a white solid (40 mg, 29\%) from compound $14(140 \mathrm{mg}, 0.336 \mathrm{mmol})$ using general procedure $B$. Purification was achieved by flash chromatography on reverse phase $\left(\mathrm{H}_{2} \mathrm{O} / \mathrm{MeOH}, 100 / 0\right.$ to $\left.50 / 50\right)$. $\mathrm{R}_{\mathrm{f}}\left(\mathrm{PrOH} / \mathrm{NH}_{4} \mathrm{OH} / \mathrm{H}_{2} \mathrm{O}, 7 / 2 / 1\right) 0.43 .{ }^{1} \mathrm{H}$ NMR (400 MHz, $\left.\mathrm{D}_{2} \mathrm{O}\right): \delta 8.30(\mathrm{~s}, 1 \mathrm{H}, \mathrm{H}-2), 8.24(\mathrm{~s}, 1 \mathrm{H}, \mathrm{H}-8), 6.07$ (d, $J=$ $\left.5.6 \mathrm{~Hz}, 1 \mathrm{H}, \mathrm{H}-1^{\prime}\right), 4.85-4.82\left(\mathrm{~m}, 1 \mathrm{H}, \mathrm{H}-2^{\prime}\right), 4.39-4.35\left(\mathrm{~m}, 2 \mathrm{H}, \mathrm{H}-3^{\prime}, \mathrm{H}-\right.$ $\left.4^{\prime}\right), 3.89-3.84\left(\mathrm{~m}, 2 \mathrm{H}, \mathrm{O}-\mathrm{CH}_{2}-\mathrm{CH}_{3}\right), 3.26-3.24\left(\mathrm{~m}, 2 \mathrm{H}, \mathrm{H}-5^{\prime}\right), 3.05-$ $2.93\left(\mathrm{~m}, 2 \mathrm{H}, \mathrm{CH}_{2}-\mathrm{P}\right), 1.13\left(\mathrm{t}, J=7.1 \mathrm{~Hz}, 3 \mathrm{H}, \mathrm{CH}_{3}\right) .{ }^{13} \mathrm{C} \mathrm{NMR}(101 \mathrm{MHz}$, $\mathrm{D}_{2} \mathrm{O}$ ): $\delta 155.6$ (C-6), 152.9 (C-2), 148.7 (C-4), 140.4 (C-8), 119.0 (C-5), 88.2 (C-1'), 81.9 (C-4'), 73.2 (C-2'), 71.6 (C-3'), 60.9 (d, J = 5.8 Hz, O-

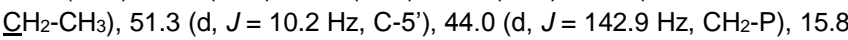
(d, $\left.J=5.9 \mathrm{~Hz}, \mathrm{CH}_{3}\right) .{ }^{31} \mathrm{P}$ NMR $\left(162 \mathrm{MHz}, \mathrm{D}_{2} \mathrm{O}\right): \delta 17.7$. Q-TOF MS E': $\mathrm{m} / \mathrm{z} 411.12(\mathrm{M}+\mathrm{H})^{+}$. Q-TOF MS E*: m/z $387.12(\mathrm{M}-\mathrm{Na})^{+}$. HRMS Q-TOF MS $E^{+}$: Calculated for $\mathrm{C}_{13} \mathrm{H}_{21} \mathrm{~N}_{6} \mathrm{O}_{6} \mathrm{NaP}[\mathrm{M}+\mathrm{H}]^{+}$411.1158; found: 411.1161. UV (EtOH abs) $\lambda_{\max }=259 \mathrm{~nm}\left(\varepsilon_{\max }=15800\right)$.

5'-Deoxy-5'-N-phosphonomethyladenosine (disodium salt) (5) The title compound was obtained as a white solid ( $29 \mathrm{mg}, 17 \%$ over the 2 steps) from compound 13 (182 $\mathrm{mg}, 0.4 \mathrm{mmol})$ using general procedure B. The residue was purified on reverse phase $\left(\mathrm{H}_{2} \mathrm{O} / \mathrm{MeOH}: 100 / 0\right)$ to give the intermediate deprotected phosphonate $(37 \mathrm{mg})$. This last was subsequently treated following procedure $A$. Purification on reverse phase $\left(\mathrm{H}_{2} \mathrm{O} / \mathrm{MeOH}\right.$ : $\left.100 / 0\right)$ followed by an ion exchange on DOWEX 50WX2 ( $\mathrm{Na}^{+}$form). ${ }^{1} \mathrm{H}$ NMR $\left(500 \mathrm{MHz}, \mathrm{D}_{2} \mathrm{O}\right.$ ): $\delta 8.27(\mathrm{~s}, 1 \mathrm{H}, \mathrm{H}-8), 8.23$ (s, $1 \mathrm{H}, \mathrm{H}-2), 6.07\left(\mathrm{~d}, J=5.4 \mathrm{~Hz}, 1 \mathrm{H}, \mathrm{H}-1^{\prime}\right), \mathrm{H}-2$ ' signal in $\mathrm{D}_{2} \mathrm{O}$ peak, $4.48-$ $4.45\left(\mathrm{~m}, 1 \mathrm{H}, \mathrm{H}-4^{\prime}\right), 4.42\left(\mathrm{t}, \mathrm{J}=4.8 \mathrm{~Hz}, 1 \mathrm{H}, \mathrm{H}^{\prime} 3^{\prime}\right), 3.60-3.52(\mathrm{~m}, 2 \mathrm{H}, \mathrm{H}$ 5'), $3.00\left(\mathrm{~d}, \mathrm{~J}=11.6 \mathrm{~Hz}, 2 \mathrm{H}, \mathrm{CH}_{2} \mathrm{P}\right) .{ }^{13} \mathrm{C}$ NMR $\left(126 \mathrm{MHz}, \mathrm{D}_{2} \mathrm{O}\right): \delta 155.5$ (C-6), 152.9 (C-2), 148.6 (C-4), 140.5 (C-8), 119.0 (C-5), 88.6 (C-1') 80.0 (C-4'), 73.2 (C-2'), 71.4 (C-3'), 50.8 (C-5'), 46.6 (d, J = $128.9 \mathrm{~Hz}$, $\left.\mathrm{CH}_{2}-\mathrm{P}\right) .{ }^{31} \mathrm{P}$ NMR (162 MHz, $\left.\mathrm{D}_{2} \mathrm{O}\right): \delta$ 7.34. Q-TOF MS E+: $\mathrm{m} / \mathrm{z} 405.07$ $(\mathrm{M}+\mathrm{H})+$. HRMS Q-TOF MS E+: calculated for $\mathrm{C}_{11} \mathrm{H}_{16} \mathrm{~N}_{6} \mathrm{O}_{6} \mathrm{PNa} 2[\mathrm{M}+\mathrm{H}]+$ 405.0664 found; 405.0663 .

\section{5'-Deoxy-5'-N-[(tetraethyl-bisphosphono)methyl]adenosine} Compound 10 (302.4 mg, $0.98 \mathrm{mmol})$, paraformaldehyde $(62.9 \mathrm{mg}, 2$ eq.) and diethylphosphite $(0.26 \mathrm{~mL}, 2$ eq.) were sealed in a microwave reactor. Under stirring, microwave irradiations were applied for $1 \mathrm{~h}$ at $100^{\circ} \mathrm{C}$ with a power of 850 Watts. The crude mixture was purified on silica gel flash chromatography $\left(\mathrm{CH}_{2} \mathrm{Cl}_{2} / \mathrm{MeOH}\right.$ : $\left.90 / 10\right)$ to afford protected intermediate $(300 \mathrm{mg}, 0.5 \mathrm{mmol})$. This latter was treated following procedure $\mathrm{A}$. The residue was co-evaporated with $\mathrm{EtOH}$ and gave, after purification on reverse phase $\left(\mathrm{H}_{2} \mathrm{O} / \mathrm{MeOH}: 100 / 0\right.$ to $\left.0 / 100\right)$ and freezedrying, the desired compound $\mathbf{1 5}$ as a white solid $(172.3 \mathrm{mg}, 31 \%)$. $\mathrm{R}_{\mathrm{f}}$ ( $\left.\mathrm{iPrOH} / \mathrm{NH}_{4} \mathrm{OH} / \mathrm{H}_{2} \mathrm{O}, 7 / 1 / 2\right)$ 0.81. ${ }^{1} \mathrm{H}$ NMR $\left(500 \mathrm{MHz}, \mathrm{CDCl}_{3}\right): \delta 8.25$ (s, $1 \mathrm{H}, \mathrm{H}-2), 8.11(\mathrm{~s}, 1 \mathrm{H}, \mathrm{H}-8), 6.27\left(\mathrm{br} \mathrm{s}, 2 \mathrm{H}, \mathrm{NH}_{2}\right), 6.01(\mathrm{~d}, J=3.9 \mathrm{~Hz}, 1 \mathrm{H}$, $\left.\mathrm{H}-1^{\prime}\right), 4.65-4.63\left(\mathrm{~m}, 1 \mathrm{H}, \mathrm{H}-2^{\prime}\right), 4.55-4.53\left(\mathrm{~m}, 1 \mathrm{H}, \mathrm{H}-3^{\prime}\right), 4.21-4.18(\mathrm{~m}$, $\left.1 \mathrm{H}, \mathrm{H}^{\prime} \mathbf{4}^{\prime}\right), 4.12-4.08\left(\mathrm{~m}, 8 \mathrm{H}, \mathrm{O}-\mathrm{CH}_{2}-\mathrm{CH}_{3}\right), 3.26-3.11\left(\mathrm{~m}, 6 \mathrm{H}, \mathrm{CH}_{2}-\mathrm{P}+\right.$ $\left.\mathrm{H}-5^{\prime}\right), 1.30-1.27\left(\mathrm{~m}, 12 \mathrm{H}, \mathrm{O}-\mathrm{CH}_{2}-\mathrm{C}_{3}\right) \cdot{ }^{13} \mathrm{C} \mathrm{NMR}\left(126 \mathrm{MHz}, \mathrm{CDCl}_{3}\right): \delta$ 155.6 (C-6), 152.9 (C-2), 149.6 (C-4), 139.6 (C-8) 119.8 (C-5), 89.2 (C$\left.1^{\prime}\right), 83.3$ (C-4'), $74.5\left(\mathrm{C}-2^{\prime}\right), 71.2\left(\mathrm{C}-3^{\prime}\right), 62.5\left(\mathrm{O}-\mathrm{CH}_{2}-\mathrm{CH}_{3}\right), 57.8\left(\mathrm{C}-5^{\prime}\right)$, $52.4\left(\mathrm{~d}, J=7.5 \mathrm{~Hz}, \mathrm{CH}_{2}-\mathrm{P}\right), 51.1\left(\mathrm{~d}, J=7.5 \mathrm{~Hz}, \mathrm{CH}_{2}-\mathrm{P}\right), 16.6\left(\mathrm{O}-\mathrm{CH}_{2}-\right.$ $\left.\mathrm{CH}_{3}\right){ }^{31} \mathrm{P}$ NMR $\left(202 \mathrm{MHz}, \mathrm{CDCl}_{3}\right): \delta$ 24.6. Q-TOF MS E+: $\mathrm{m} / \mathrm{z} 567.21$ $(\mathrm{M}+\mathrm{H})^{+}$. HRMS Q-TOF MS E+: calculated for $\mathrm{C}_{20} \mathrm{H}_{37} \mathrm{~N}_{6} \mathrm{O}_{9} \mathrm{P}_{2}[\mathrm{M}+\mathrm{H}]^{+}$ 567.2097; found 567.2103

5'-Deoxy-5'- $N$-[(bisphosphono)methyl]adenosine (tetra sodium salt) (6) The title compound was obtained as a white solid (158 mg, quantitative yield) from compound $15(165 \mathrm{mg}, 0.3 \mathrm{mmol})$ using general procedure B. After stirred at room temperature for $24 \mathrm{~h}$, trimethylsilyl bromide $(200 \mu \mathrm{L}, 5$ eq.) was added and the mixture stirred at room temperature for $5 \mathrm{~h}$. Purification by reverse-phase column chromatography with $\mathrm{H}_{2} \mathrm{O}$ followed by ion exchange on DOWEX 50WX2 $\left(\mathrm{Na}^{+}\right.$form) provided compound 6 as a white solid $(158 \mathrm{mg}$, quantitative yield). ${ }^{1} \mathrm{H}$ NMR (500 MHz, $\left.\mathrm{D}_{2} \mathrm{O}\right): \delta 8.38(\mathrm{~s}, 1 \mathrm{H}, \mathrm{H}-2), 8.30(\mathrm{~s}, 1 \mathrm{H}, \mathrm{H}-8)$, 
$6.14\left(\mathrm{~d}, J=5.3 \mathrm{~Hz}, 1 \mathrm{H}, \mathrm{H}-1^{\prime}\right), \mathrm{H}-2^{\prime}$ signal in $\mathrm{D}_{2} \mathrm{O}$ peak, $4.67-4.63(\mathrm{~m}$ $\left.1 \mathrm{H}, \mathrm{H}-4^{\prime}\right), 4.43-4.41\left(\mathrm{~m}, 1 \mathrm{H}, \mathrm{H}-3^{\prime}\right), 4.06-3.84\left(\mathrm{~m}, 2 \mathrm{H}, \mathrm{H}-5^{\prime}\right), 3.61-$ $3.47\left(\mathrm{~m}, 4 \mathrm{H}, \mathrm{CH}_{2}-\mathrm{P}\right) .{ }^{13} \mathrm{C} \mathrm{NMR}\left(126 \mathrm{MHz}, \mathrm{D}_{2} \mathrm{O}\right): \delta 155.4(\mathrm{C}-6), 152.6(\mathrm{C}-$ 2), 148.7 (C-4), 140.7 (C-8), 119.2 (C-5), 88.7 (C-1'), 78.7 (C-4'), 73.1 (C2'), $71.6\left(\mathrm{C}-3^{\prime}\right), 58.1\left(\mathrm{C}-5^{\prime}\right), 52.6\left(\mathrm{CH}_{2} \mathrm{P}\right), 51.6\left(\mathrm{CH}_{2} \mathrm{P}\right) .{ }^{31} \mathrm{P}$ NMR (121 $\left.\mathrm{MHz}, \mathrm{D}_{2} \mathrm{O}\right): \delta$ 7.9. Q-TOF MS E*: m/z $475.05(\mathrm{M}-\mathrm{H})^{-}$. HRMS Q-TOF MS $E^{*}$ : calculated for $\mathrm{C}_{12} \mathrm{H}_{18} \mathrm{~N}_{6} \mathrm{O}_{9} \mathrm{NaP}_{2}[\mathrm{M}-\mathrm{H}]-475.0508$; found 475.0511 .

5'-Deoxy-5'- $N$-[(diethoxyphosphorylethylacetate)]-2', 3'-O-isopropylidene-adenosine (16) To a stirred solution of $10(419.4 \mathrm{mg}, 1.37 \mathrm{mmol})$ in freshly distilled dichloromethane $(7 \mathrm{~mL})$ was added $\mathrm{MgSO}_{4}(300 \mathrm{mg}, 5$ eq.) and ethylglyoxylate (50\% solution (wt.) in toluene, $272 \mu \mathrm{L}, 1.2$ eq.) under an argon atmosphere. After stirring at room temperature for $3 \mathrm{~h}$, the mixture was filtered and concentrated in vacuum to afford the intermediate imine. It was transferred in a microwave reactor and diethyl phosphite $(700 \mu \mathrm{L}, 4$ eq.) was added, then the mixture was irradiated by microwave for $6 \mathrm{~h}$ at $100^{\circ} \mathrm{C}$ with a power of 850 Watts. Purification by flash chromatography on silica gel $\left(\mathrm{CH}_{2} \mathrm{Cl}_{2} / \mathrm{MeOH}\right.$ : 90/10) afforded $1 / 1$ mixture of diastereomers 16 as a white solid $(375 \mathrm{mg}, 53 \%)$. $\mathrm{R}_{\mathrm{f}}$ $\left(\mathrm{CH}_{2} \mathrm{Cl}_{2} / \mathrm{MeOH}, 9 / 1\right)$ 0.48. ${ }^{1} \mathrm{H} \mathrm{NMR}\left(500 \mathrm{MHz}, \mathrm{CDCl}_{3}\right): \delta 8.39(\mathrm{~s}, 1 \mathrm{H}, \mathrm{H}-2$, dia1 or dia2), $8.36(\mathrm{~s}, 1 \mathrm{H}, \mathrm{H}-2$, dia1 or dia2), $8.06(\mathrm{~s}, 1 \mathrm{H}, \mathrm{H}-8$, dia1 or dia2), 7.95 (s, $1 \mathrm{H}, \mathrm{H}-8$, dia1 or dia2), 6.06 (d, $J=2.9 \mathrm{~Hz}, 1 \mathrm{H}, \mathrm{H}-1$ ', dia1), 6.03 (d, $J=3.2 \mathrm{~Hz}, 1 \mathrm{H}, \mathrm{H}-1$ ', dia2), 5.74 (br s, $4 \mathrm{H}, \mathrm{NH}_{2}$, dia1 + dia2), 5.42 (dd, $J=6.5,3.0 \mathrm{~Hz}, 1 \mathrm{H}, \mathrm{H}-2$ ', dia1), 5.39 (dd, $J=6.4,3.2 \mathrm{~Hz}, 1 \mathrm{H}, \mathrm{H}-2$ ', dia2), 5.07 (dd, $J=6.4,3.2 \mathrm{~Hz}, 1 \mathrm{H}, \mathrm{H}-3^{\prime}$, dia2), 5.02 (dd, $J=6.5,3.4 \mathrm{~Hz}$, 1H, H-3', dia1), 4.37 - 4.32 (m, 2H, H-4', dia1 + dia2), $4.24-4.11(\mathrm{~m}$, $12 \mathrm{H}, \mathrm{O}-\mathrm{CH}_{2}-\mathrm{CH}_{3}$, dia1 + dia2), 3.77 (s, $1 \mathrm{H}, \mathrm{CHP}$, dia1 or dia2), 3.72 (s, $1 \mathrm{H}, \mathrm{CHP}$, dia1 or dia2), 3.10 (dd, $J=4.0,12.7 \mathrm{~Hz}, 1 \mathrm{H}, \mathrm{H}-5$ ', dia2), 2.98$2.86\left(\mathrm{~m}, 2 \mathrm{H}, \mathrm{H}-5^{\prime}\right.$, dia1 + dia2), 2.79 (dd, $J=3.8,12.7 \mathrm{~Hz}, 1 \mathrm{H}, \mathrm{H}-5^{\prime}$ dia2), 1.61 (s, $\left.6 \mathrm{H}, \mathrm{CH}_{3} \mathrm{dia} 1+\mathrm{dia} 2\right), 1.38$ (s, $\left.6 \mathrm{H}, \mathrm{CH}_{3}, \mathrm{dia} 1+\mathrm{dia} 2\right), 1.33-1.29$ (m, $12 \mathrm{H}, \mathrm{O}-\mathrm{CH}_{2}-\mathrm{CH}_{3}$, dia1 + dia2), $1.24-1.21\left(\mathrm{~m}, 6 \mathrm{H}, \mathrm{O}-\mathrm{CH}_{2}-\mathrm{CH}_{3}\right.$, dia1 + dia2). ${ }^{13} \mathrm{C}$ NMR (126 MHz, $\mathrm{CDCl}_{3}$ ): $\delta 169.2$ (CO, dia1 or dia2), 169.1 (CO, dia1 or dia2), 155.6 (C-6, dia1 + dia2), 153.5 (C-2, dia1 or dia2), 153.3(C-2, dia1 or dia2), 149.6 (C-4, dia1 + dia2), 140.1 (C-8, dia1), 139.9 (C-8, dia2), 120.5 (C-5, dia1 or dia2), 120.4 (C-5, dia1 or dia2), $114.8\left(\mathrm{C}\left(\mathrm{CH}_{3}\right)_{2}\right.$, dia1), $114.7\left(\underline{\mathrm{C}}\left(\mathrm{CH}_{3}\right)_{2}\right.$, dia2), $91.0\left(\mathrm{C}-1^{\prime}, \mathrm{dia} 2\right), 90.4\left(\mathrm{C}-1^{\prime}\right.$, dia1), 86.3 (C-4', dia1), 85.9 (C-4', dia2), 83.9 (C-2', dia1), 83.7 (C-2', dia2), 82.3 (C-3', dia1 + dia2), $63.6\left(\mathrm{O}-\underline{\mathrm{C}} \mathrm{H}_{2}-\mathrm{CH}_{3}\right.$, dia1 + dia2), $63.5-$ $63.4\left(\mathrm{O}-\mathrm{CH}_{2}-\mathrm{CH}_{3}\right.$, dia1 + dia2), $61.9\left(\mathrm{O}-\underline{\mathrm{C}} \mathrm{H}_{2}-\mathrm{CH}_{3}\right.$, dia1 + dia2), $61.4-$ 61.3 (CHP, dia1 or dia2), 60.2 (CHP, dia1 or dia2), $50.8-50.6$ (C-5', dia1 + dia2), $27.5\left(\mathrm{CH}_{3}, \mathrm{dia} 1\right.$ + dia2 $), 27.4\left(\mathrm{CH}_{3}, \mathrm{dia} 1+\mathrm{dia} 2\right), 16.6-$ $16.5\left(\mathrm{P}-\mathrm{O}-\mathrm{CH}_{2}-\mathrm{CH}_{3}\right.$, dia1 + dia2), $14.2\left(\mathrm{C}-\mathrm{O}-\mathrm{CH}_{2}-\mathrm{CH}_{3}\right.$, dia1 + dia2). ${ }^{31} \mathrm{P}$ $\operatorname{NMR}\left(202 \mathrm{MHz}, \mathrm{CDCl}_{3}\right): \delta 17.6$ (dia1 or dia2), 17.5 (dia1 or dia2). Q-TOF MS $E^{+}: m / z \quad 529.22(M+H)^{+}$. HRMS Q-TOF MS $E^{+}$: calculated for $\mathrm{C}_{21} \mathrm{H}_{34} \mathrm{~N}_{6} \mathrm{O}_{8} \mathrm{P}[\mathrm{M}+\mathrm{H}]^{+}$529.2176; found 529.2177.

5'-Deoxy-5'- $N$-[(diethoxyphosphorylethylacetate)]adenosine (17) The title compound was obtained as a white solid $(330.2 \mathrm{mg}, 98 \%)$ from compound 16 (365.2 mg, $0.69 \mathrm{mmol})$ using general procedure $A$. Purification was carried by flash chromatography on silica gel $\left.\left(\mathrm{CH}_{2} \mathrm{Cl}_{2} / \mathrm{MeOH}, 9 / 1\right)\right)$. $\mathrm{R}_{\mathrm{f}}\left(\mathrm{CH}_{2} \mathrm{Cl}_{2} / \mathrm{MeOH}, 9 / 1\right)$ 0.32. ${ }^{1} \mathrm{H} \mathrm{NMR}(300 \mathrm{MHz}$, $\left.\mathrm{CD}_{3} \mathrm{OD}\right): \delta 8.36-8.26(\mathrm{~m}, 4 \mathrm{H}, \mathrm{H}-2 \& \mathrm{H}-8$, dia1 + dia2), $5.98(\mathrm{~d}, J=5.5$ $\mathrm{Hz}, 1 \mathrm{H}, \mathrm{H}-1^{\prime}$, dia1), $5.94\left(\mathrm{~d}, J=5.9 \mathrm{~Hz}, 1 \mathrm{H}, \mathrm{H}-1^{\prime}\right.$, dia2), $\mathrm{H}-2$ ' dia2 signal in $\mathrm{H}_{2} \mathrm{O}$ peak), $4.80-4.77(\mathrm{~m}, 1 \mathrm{H}, \mathrm{H}-2$ ', dia1), 4.38 (dd, $J=5.3,3.5 \mathrm{~Hz}, 1 \mathrm{H}$, $\left.\mathrm{H}-3^{\prime}, \mathrm{dia} 2\right), 4.26-4.10\left(\mathrm{~m}, 15 \mathrm{H}, \mathrm{O}-\mathrm{CH}_{2}-\mathrm{CH}_{3}, \mathrm{H}-3^{\prime}\right.$ dia1 and $\mathrm{H}-4$ ' dia1 + dia2), 3.15 (dd, $J=12.8,3.1 \mathrm{~Hz}, 1 \mathrm{H}, \mathrm{H}-5^{\prime}$ dia2), $3.03-3.00$ (m, 2H, H-5', dia1 + dia2), 2.83 (dd, $J=12.8,4.9 \mathrm{~Hz}, 1 \mathrm{H}, \mathrm{H}-5$, dia2), $1.34-1.20$ (m, $18 \mathrm{H}, \mathrm{O}-\mathrm{CH}_{2}-\mathrm{CH}_{3}$, dia1 + dia2). ${ }^{13} \mathrm{C}$ NMR $\left(126 \mathrm{MHz}, \mathrm{CD}_{3} \mathrm{OD}\right): \delta 170.4$ (CO, dia1 + dia2), 156.6 (C-6, dia1 or dia2), 156.4 (C-6, dia1 or dia2), 152.8 (C-2, dia1), 152.7 (C-2, dia2), 150.6 (C-4, dia1), 150.5 (C-4, dia2), 142.5 (C-8, dia2), 142.1 (C-8, dia1), 120.8 (C-5, dia2), 120.7 (C-5, dia1), 90.8 (C-1', dia2), 90.4 (C-1', dia1), 86.3 (C-4', dia2), 85.9 (C-4', dia1), 75.0 (C-2', dia1), 74.6 (C-2', dia2), 73.0 (C-3', dia1), 72.9 (C-3', dia2), $65.3-64.8\left(\mathrm{~m}, \mathrm{O}-\mathrm{CH}_{2}-\mathrm{CH}_{3}\right.$, dia1 + dia2), 63.0 (CHP, dia1 + dia2), $51.9-$ 51.4 (C-5', dia1 + dia2), $16.8-14.4\left(\mathrm{~m}, \mathrm{C}(\mathrm{O}) \mathrm{CH}_{2}-\mathrm{CH}_{3}\right.$ and $\mathrm{P}(\mathrm{O})-\mathrm{CH}_{2-}$ $\mathrm{CH}_{3}$, dia1 + dia2). ${ }^{31} \mathrm{P}$ NMR (202 MHz, $\left.\mathrm{CD}_{3} \mathrm{OD}\right): \delta 18.4$ (dia1 or dia2), 18.3 (dia1 or dia2). Q-TOF MS E+: m/z $489.19(\mathrm{M}+\mathrm{H})^{+}$. HRMS Q-TOF $M S E^{+}$: calculated for $\mathrm{C}_{18} \mathrm{H}_{30} \mathrm{~N}_{6} \mathrm{O}_{8} \mathrm{P}[\mathrm{M}+\mathrm{H}]^{+}$489.1863; found 489.1866 .
5'-Deoxy-5'-N-[(ethoxyphosphorylacetate)]adenosine

(disodium salt) (7) The title compound was obtained as a white solid $(71.6 \mathrm{mg}$ $78 \%$ ) from compound 17 (94.5 $\mathrm{mg}, 0.19 \mathrm{mmol})$ using general procedure B. Purification by reverse-phase column chromatography with $\mathrm{H}_{2} \mathrm{O} / \mathrm{MeOH}(100 / 0$ to $0 / 100)$ afford the desired intermediate as a triethylammonium salt. This last was treated with $\mathrm{NaOH}$ solution (1M in $\mathrm{H}_{2} \mathrm{O}, 300 \mu \mathrm{L}, 1.5$ eq.) and the mixture was stirred at room temperature overnight. The mixture was neutralized with a saturated aqueous solution of $\mathrm{NH}_{4} \mathrm{Cl}$. After freeze-drying, purification by reverse phase column chromatography with $\mathrm{H}_{2} \mathrm{O} / \mathrm{MeOH}(100 / 0$ to $0 / 100)$ and ion exchange on DOWEX 50WX2 ( $\mathrm{Na}^{+}$form) afforded the desired mixture of diastereomers 7. $\mathrm{R}_{\mathrm{f}}\left(\mathrm{iPrOH} / \mathrm{NH}_{4} \mathrm{OH} / \mathrm{H}_{2} \mathrm{O}, 7 / 1 / 2\right) 0.62 .{ }^{1} \mathrm{H} \mathrm{NMR}(500 \mathrm{MHz}$, $\left.\mathrm{D}_{2} \mathrm{O}\right): \delta 8.33-8.29(\mathrm{~m}, 4 \mathrm{H}, \mathrm{H}-2$ and $\mathrm{H}-8$, dia1 + dia2), $6.11-6.09(\mathrm{~m}$, $2 \mathrm{H}, \mathrm{H}-1$ ', dia1 + dia2), $\mathrm{H}-2$ ' dia1 + dia2 signal in $\mathrm{D}_{2} \mathrm{O}$ peak, $4.55-4.48$ (m, 4H, H-4' and H-3', dia1 + dia2), 4.01-3.86 (m, 6H, CHP and O- $\underline{\mathrm{H}}_{2}$ $\mathrm{CH}_{3}$, dia1 + dia2), $3.75-3.60(\mathrm{~m}, 4 \mathrm{H}, \mathrm{H}-5$ ', dia1 + dia2), $1.17-1.09(\mathrm{~m}$, $6 \mathrm{H}, \mathrm{CH}_{3}$, dia1 + dia2). ${ }^{13} \mathrm{C}$ NMR (126 MHz, $\left.\mathrm{D}_{2} \mathrm{O}\right): \delta 168.9(\mathrm{CO}$, dia1 + dia2), 155.2 (C-6, dia1 + dia2), 152.4 (C-2, dia1 or dia2), 152.3 (C-2, dia1 or dia2), 148.5 (C-4, dia2), 148.4 (C-4, dia1), 141.2 (C-8, dia1 + dia2), 119.4 (C-5, dia1 + dia2), 89.4 (C-1', dia1 + dia2), 79.9 (C-4', dia2), 79.2 (C-4', dia1), 73.3 (C-2', dia1), 73.0 (C-2', dia2), 71.5 (C-3', dia1), 71.4 (C3', dia2), 62.6 - 59.9 (m, CHP and $\mathrm{O}-\mathrm{CH}_{2}-\mathrm{CH}_{3}$, dia1 + dia2), $49.3-48.8$ (m, C-5', dia1 + dia2), $15.9-15.8\left(\mathrm{~m}, \mathrm{CH}_{3}\right.$, dia1 + dia2). ${ }^{31} \mathrm{P}$ NMR (202 $\mathrm{MHz}, \mathrm{D}_{2} \mathrm{O}$ ): $\delta 7.9$ (dia1 or dia2), 7.8 (dia1 or dia2). Q-TOF MS $\mathrm{E}^{+}: \mathrm{m} / \mathrm{z}$ $477.09(\mathrm{M}+\mathrm{H})^{+}$. HRMS Q-TOF MS E+: calculated for $\mathrm{C}_{14} \mathrm{H}_{20} \mathrm{~N}_{6} \mathrm{O}_{8} \mathrm{PNa}_{2}$ $[\mathrm{M}+\mathrm{H}]^{+}$477.0876; found 477.0876 .

5'-Deoxy-5'- $N$-[(phosphorylacetate)]adenosine (tri sodium salt) (8) The title compound was obtained as a white solid $(78.9 \mathrm{mg}, 77 \%)$ from compound 17 (219.2 mg, $0.45 \mathrm{mmol}$ ) using general procedure $B$. Purification was carried out by reverse phase column chromatography with $\mathrm{H}_{2} \mathrm{O} / \mathrm{MeOH}(100 / 0$ to $0 / 100)$ to afford desired compound as a triethylammonium salt. This last was then dissolved in a $\mathrm{NaOH}$ solution ( $1 \mathrm{M}$ in $\mathrm{H}_{2} \mathrm{O}, 2.1 \mathrm{~mL}, 10$ eq.) and stirred at room temperature for a week the solution was adjusted to $\mathrm{pH}=5$ with an ion exchange resin DOWEX $50 \mathrm{WX} 2\left(\mathrm{H}^{+}\right.$form). Freeze drying, followed by reverse phase column chromatography with $\mathrm{H}_{2} \mathrm{O} / \mathrm{MeOH}(0$ to 100$)$ and ion exchange on DOWEX 50WX2 ( $\mathrm{Na}^{+}$form) provided the desired mixture of diastereomers 8. $\mathrm{R}_{\mathrm{f}}\left(\mathrm{iPrOH} / \mathrm{NH}_{4} \mathrm{OH} / \mathrm{H}_{2} \mathrm{O}, 5 / 1 / 4\right)$ 0.22. ${ }^{1} \mathrm{H}$ NMR $(500 \mathrm{MHz}$, $\left.\mathrm{D}_{2} \mathrm{O}\right): \delta 8.28(\mathrm{~d}, 2 \mathrm{H}, \mathrm{H}-8$, dia1 + dia2), $8.22(\mathrm{~d}, 2 \mathrm{H}, \mathrm{H}-2$, dia1 + dia2), 6.09 $-6.06\left(\mathrm{~m}, 2 \mathrm{H}, \mathrm{H}-1\right.$ ', dia1 + dia2), $\mathrm{H}-2$ ' dia1 + dia2 signal in $\mathrm{D}_{2} \mathrm{O}$ peak, $4.53-4.48(\mathrm{~m}, 2 \mathrm{H}, \mathrm{H}-4$ ', dia1 + dia2), $4.46-4.44(\mathrm{~m}, 1 \mathrm{H}, \mathrm{H}-3$ ', dia1) 4.41 - 4.39 (m, 1H, H-3', dia2), 3.76 (t, $J=14.0 \mathrm{~Hz}, 2 \mathrm{H}, \mathrm{CHP}$, dia1 + dia2), $3.69-3.52(\mathrm{~m}, 4 \mathrm{H}, \mathrm{H}-5$ ', dia $1+$ dia 2$) .{ }^{13} \mathrm{C} \mathrm{NMR}\left(126 \mathrm{MHz}, \mathrm{D}_{2} \mathrm{O}\right)$ $\delta 171.7$ - $171.6(\mathrm{~m}, \mathrm{CO}$, dia1 + dia2), 155.4 (C-6, dia1 + dia2), 153.0 (C2, dia1), 152.8 (C-2, dia2), 148.5 (C-4, dia1 + dia2), 140.5 (C-8, dia1 or dia2), 140.4 (C-8, dia1 or dia2), 119.0 (C-5, dia1 + dia2), 88.8 (C-1', dia1), 88.6 (C-1', dia2), 79.8 (C-4', dia1), 79.5 (C-4', dia2), 73.4 (C-2', dia2), 73.2 (C-2', dia1), 71.4 (C-3', dia2), 71.2 (C-3', dia1), 64.2 - 63.1 (m, CHP, dia1 + dia2), 50.1 - 49.9 (m, C-5', dia1 + dia2). ${ }^{31} \mathrm{P}$ NMR (202 MHz, $\mathrm{D}_{2} \mathrm{O}$ ): $\delta 5.8$ (dia1 + dia2). Q-TOF MS E+: m/z $405.09(\mathrm{M}+\mathrm{H})^{+}$. HRMS QTOF MS E+: calculated for $\mathrm{C}_{12} \mathrm{H}_{18} \mathrm{~N}_{6} \mathrm{O}_{8} \mathrm{P}[\mathrm{M}+\mathrm{H}]^{+}$405.0924; found 405.0921.

\section{9-(2,3-O-isopropylidene- $\beta$-D-ribofuranosyl)-6-(2,5-dimethylpyrrol-1-} yl)purine (18) ${ }^{[16]}$ Compound 18 was obtained from commercially available adenosine with $36 \%$ yield according previously published procedure. ${ }^{[16]}$ Characterization $\left({ }^{1} \mathrm{H}\right)$ was in agreement with the literature. $\mathrm{R}_{\mathrm{f}}\left(\right.$ Petroleum ether / EtOAc, 7/3) 0.23. ${ }^{1} \mathrm{H} \mathrm{NMR}\left(400 \mathrm{MHz}, \mathrm{CDCl}_{3}\right): \delta$ $8.92(\mathrm{~s}, 1 \mathrm{H}, \mathrm{H}-2), 8.17(\mathrm{~s}, 1 \mathrm{H}, \mathrm{H}-8), 6.00(\mathrm{~s}, 2 \mathrm{H}, \mathrm{CH}), 5.98(\mathrm{~d}, J=5.0 \mathrm{~Hz}$, $\left.1 \mathrm{H}, \mathrm{H}-1^{\prime}\right), 5.32-5.29$ (m, 1H, H-2'), 5.16 (dd, J=5.9, $\left.1.2 \mathrm{~Hz}, 1 \mathrm{H}, \mathrm{H}-3^{\prime}\right)$, 4.59 (s, $\left.1 \mathrm{H}, \mathrm{H}-4^{\prime}\right), 4.02$ and 3.85 (AB, J = 12.8, $1.8 \mathrm{~Hz}, 2 \mathrm{H}, \mathrm{H}-5$ '), 2.21 (s, $\left.6 \mathrm{H}, \mathrm{CH}_{3}\right), 1.67$ (s, 3H, CH $\left.\mathrm{H}_{3}\right), 1.40\left(\mathrm{~s}, 3 \mathrm{H}, \mathrm{CH}_{3}\right)$.

9-(5-azido-5-deoxy-2,3-O-isopropylidene- $\beta$-D-ribofuranosyl)-6-(2,5dimethylpyrrol-1-yl)purine (19) To a stirred solution of compound 18 (300 $\mathrm{mg}, 0.78 \mathrm{mmol}$ ) in anhydrous 1.4-dioxane $(3 \mathrm{~mL})$ was added diphenyl phosphoryl azide (336 $\mu \mathrm{L}, 2$ eq.) and 1,8- 
diazabicyclo[5.4.0]undec-7-ene (350 $\mu \mathrm{L}, 3$ eq.) under an argon atmosphere. The mixture was stirred overnight at room temperature before the addition of sodium azide (253 mg, 5 eq.) and a catalytic amount of crown ether (15-crown-5, $1.7 \mathrm{mg}, 0.01 \mathrm{eq}$.). This mixture was heated at reflux for $4 \mathrm{~h}$, before filtration and concentration to dryness under reduced pressure. Purification by column chromatography with Petroleum ether/EtOAc (80/20) afforded compound 19 as a white solid (319 mg, quantitative yield). Rf (Petroleum ether/EtOAc, 7/3) 0.73. ${ }^{1} \mathrm{H}$ $\operatorname{NMR}\left(600 \mathrm{MHz}, \mathrm{CDCl}_{3}\right): \delta 8.95(\mathrm{~s}, 1 \mathrm{H}, \mathrm{H}-2), 8.24(\mathrm{~s}, 1 \mathrm{H}, \mathrm{H}-8), 6.23(\mathrm{~d}, J$ $\left.=2.5 \mathrm{~Hz}, 1 \mathrm{H}, \mathrm{H}-1^{\prime}\right), 5.99(\mathrm{~s}, 2 \mathrm{H}, 2 \mathrm{xCH}), 5.48-5,47\left(\mathrm{~m}, 1 \mathrm{H}, \mathrm{H}-2^{\prime}\right), 5.08-$ $5.07\left(\mathrm{~m}, 1 \mathrm{H}, \mathrm{H}-3^{\prime}\right), 4.44-4.42\left(\mathrm{~m}, 1 \mathrm{H}, \mathrm{H}-4^{\prime}\right), 3.69-3.62\left(\mathrm{~m}, 2 \mathrm{H}, \mathrm{H}-5^{\prime}\right)$, $2.20\left(\mathrm{~s}, 6 \mathrm{H}, \mathrm{CH}_{3}\right.$ pyrrole), $1.65\left(\mathrm{~s}, 3 \mathrm{H}, \mathrm{CH}_{3}\right), 1.41\left(\mathrm{~s}, 3 \mathrm{H}, \mathrm{CH}_{3}\right) .{ }^{13} \mathrm{C} \mathrm{NMR}$ (151 MHz, CDCl3): $\delta 152.9$ (C-4), 152.7 (C-2), $150.8(\mathrm{Cq}), 143.9$ (C-8), 130.0 (C-5), $129.4(\mathrm{C}-6), 115.4(\mathrm{Cq}), 109.3(\mathrm{CH}), 90.7\left(\mathrm{C} 1^{\prime}\right), 85.2\left(\mathrm{C}-4^{\prime}\right)$, 84.1 (C-2'), 81.8 (C-3'), 52.4 (C-5'), $27.4\left(\mathrm{CH}_{3}\right), 25.5\left(\mathrm{CH}_{3}\right), 13.7\left(\mathrm{CH}_{3}\right)$. Q-TOF MS E': m/z $411.19(\mathrm{M}+\mathrm{H})^{+}$. HRMS Q-TOF MS E': calculated for $\mathrm{C}_{19} \mathrm{H}_{23} \mathrm{~N}_{8} \mathrm{O}_{3}[\mathrm{M}+\mathrm{H}]^{+}$411.1893; found 411.1891.

\section{9-(5-amino-5-deoxy-2,3-O-isopropylidene- $\beta$-D-ribofuranosyl)-6-(2,5-} dimethylpyrrol-1-yl)purine (20) Compound 19 (587.5 mg, $1.4 \mathrm{mmol})$ was dissolved in absolute ethanol $(7 \mathrm{~mL})$ then Palladium on carbon $10 \%$ (44 mg, 0.03 eq.) was added and the heterogeneous mixture was stirred overnight under a hydrogen atmosphere. After filtration through a pad of Celite, the residual mixture was concentrated in vacuum. Purification by column chromatography with $\mathrm{CH}_{2} \mathrm{Cl}_{2} / \mathrm{MeOH}(90 / 10)$ afforded compound 20 as a white solid $(539 \mathrm{mg}, 98 \%) . \mathrm{R}_{\mathrm{f}}\left(\mathrm{CH}_{2} \mathrm{Cl}_{2} / \mathrm{MeOH}, 9 / 1\right) 0.58 .{ }^{1} \mathrm{H}$ NMR $\left(600 \mathrm{MHz}, \mathrm{CDCl}_{3}\right): \delta 8.93(\mathrm{~s}, 1 \mathrm{H}, \mathrm{H}-2), 8.28(\mathrm{~s}, 1 \mathrm{H}, \mathrm{H}-8), 6.15(\mathrm{~d}, J=3.3$ $\left.\mathrm{Hz}, 1 \mathrm{H}, \mathrm{H}-1^{\prime}\right), 5.98(\mathrm{~s}, 2 \mathrm{H}, 2 \mathrm{CCH}), 5.48-5.46\left(\mathrm{~m}, 1 \mathrm{H}, \mathrm{H}-2^{\prime}\right), 5.07-5.06$ (m, 1H, H-3'), $4.33-4.31\left(\mathrm{~m}, 1 \mathrm{H}, \mathrm{H}-4^{\prime}\right), 3.13-3.02\left(\mathrm{~m}, 2 \mathrm{H}, \mathrm{H}-5^{\prime}\right), 2.20$ (s, $\left.6 \mathrm{H}, \mathrm{CH}_{3}\right), 1.65\left(\mathrm{~s}, 3 \mathrm{H}, \mathrm{CH}_{3}\right), 1.40\left(\mathrm{~s}, 3 \mathrm{H}, \mathrm{CH}_{3}\right) .{ }^{13} \mathrm{C} \mathrm{NMR}(151 \mathrm{MHz}$, $\mathrm{CDCl}_{3}$ ): $\delta 153.0$ (C-4), 152.6 (C-2), 150.7 (Cq), 144.2 (C-8), 129.9 (C-5), 129.5 (C-6), $115.2(\mathrm{C}), 109.3(\mathrm{CH}), 90.9\left(\mathrm{C}^{\prime}{ }^{\prime}\right), 87.1\left(\mathrm{C}-4^{\prime}\right), 83.8\left(\mathrm{C}-2^{\prime}\right)$, $81.8\left(\mathrm{C}-3^{\prime}\right), 43.7\left(\mathrm{C}-5^{\prime}\right), 27.4\left(\mathrm{CH}_{3}\right), 25.5\left(\mathrm{CH}_{3}\right), 13.7\left(\mathrm{CH}_{3}\right)$. Q-TOF MS $\mathrm{E}^{+}: \mathrm{m} / \mathrm{z} 385.20(\mathrm{M}+\mathrm{H})^{+}$. HRMS Q-TOF MS E+: calculated for $\mathrm{C}_{19} \mathrm{H}_{25} \mathrm{~N}_{6} \mathrm{O}_{3}$ $[\mathrm{M}+\mathrm{H}]^{+}$385.1988; found 385.1986.

\section{9-(5-deoxy-2,3-O-isopropylidene- $\beta$-D-ribofuranosyl-5-N[(tetraethyl} (methylene bisphosphonate))]-6-(2,5-dimethylpyrrol-1-yl)- purine (21) Compound 20 (260mg, $0.68 \mathrm{mmol})$, triethyl orthoformiate $(135 \mu \mathrm{L}$, 1.2 eq.) and diethylphosphite (306 $\mu \mathrm{L}, 3.5$ eq.) were sealed in a microwave reactor under stirring. Microwave irradiations were applied for $2 \mathrm{~h}$ at $125^{\circ} \mathrm{C}$ with a power of 850 Watts. The resulting brown oil was purified by column chromatography $\mathrm{CH}_{2} \mathrm{Cl}_{2} / \mathrm{MeOH}(95 / 5)$ to afford the (aminomethylene) bisphosphonate $\mathbf{2 1}$ as a white solid (157 mg, 34\%). $\mathrm{R}_{\mathrm{f}}$ $\left(\mathrm{CH}_{2} \mathrm{Cl}_{2} / \mathrm{MeOH}, 9 / 1\right)$ 0.72. ${ }^{1} \mathrm{H} \mathrm{NMR}\left(500 \mathrm{MHz}, \mathrm{CDCl}_{3}\right): \delta 9.01(\mathrm{~s}, 1 \mathrm{H}, \mathrm{H}-2)$ $8.33(\mathrm{~s}, 1 \mathrm{H}, \mathrm{H}-8), 6.12\left(\mathrm{~d}, J=3.8 \mathrm{~Hz}, 1 \mathrm{H}, \mathrm{H}-1^{\prime}\right), 5.98(\mathrm{~s}, 2 \mathrm{H}, 2 \times \mathrm{CH}), 5.43$ (dd, $\left.J=6.5,3.8 \mathrm{~Hz}, 1 \mathrm{H}, \mathrm{H}-2^{\prime}\right), 5.13\left(\mathrm{dd}, J=6.5,3.2 \mathrm{~Hz}, 1 \mathrm{H}, \mathrm{H}-3^{\prime}\right), 4.40-$ $4.38\left(\mathrm{~m}, 1 \mathrm{H}, \mathrm{H}-4^{\prime}\right), 4.23-4.15\left(\mathrm{~m}, 8 \mathrm{H}, \mathrm{O}-\mathrm{CH}_{2}\right), 3.41-3.32(\mathrm{~m}, 2 \mathrm{H}, \mathrm{H}-5$ ' and $\mathrm{CHP}), 3.11-3.08\left(\mathrm{~m}, 1 \mathrm{H}, \mathrm{H}-5^{\prime}\right), 2.20\left(\mathrm{~s}, 6 \mathrm{H}, \mathrm{CH}_{3}\right), 1.64\left(\mathrm{~s}, 3 \mathrm{H}, \mathrm{CH}_{3}\right)$ $1.39\left(\mathrm{~s}, 3 \mathrm{H}, \mathrm{CH}_{3}\right), 1.32-1.27\left(\mathrm{~m}, 12 \mathrm{H}, \mathrm{O}-\mathrm{CH}_{2}-\mathrm{CH}_{3}\right) .{ }^{13} \mathrm{C} \mathrm{NMR}(101 \mathrm{MHz}$, $\mathrm{CDCl}_{3}$ ): $\delta 153.2$ (C-4), 152.9 (C-2), 150.7 (Cq), 144.0 (C-8), 130.0 (C-5), 129.4 (C-6), 115.1 (Cq), $109.2(\mathrm{CH}), 90.8$ (C-1'), 85.7 (C-4'), 83.5 (C-2'), 81.9 (C-3'), $63.3-63.0\left(\mathrm{~m}, \mathrm{O}-\mathrm{CH}_{2}\right), 56.3-53.4(\mathrm{~m}, \mathrm{CHP}), 51.5\left(\mathrm{C}-5^{\prime}\right)$, $27.5\left(\mathrm{CH}_{3}\right), 25.6\left(\mathrm{CH}_{3}\right), 16.6\left(\mathrm{O}-\mathrm{CH}_{2}-\mathrm{CH}_{3}\right), 13.7\left(\mathrm{CH}_{3}\right) .{ }^{31} \mathrm{P}$ NMR (202 $\left.\mathrm{MHz}, \mathrm{CDCl}_{3}\right): \delta 19.5-19.0(\mathrm{~m}, 2 \mathrm{P})$. Q-TOF MS E+: $\mathrm{m} / \mathrm{z} 671.27(\mathrm{M}+\mathrm{H})^{+}$. HRMS Q-TOF MS E+: calculated for $\mathrm{C}_{28} \mathrm{H}_{45} \mathrm{~N}_{6} \mathrm{O}_{9} \mathrm{P}_{2}[\mathrm{M}+\mathrm{H}]^{+}$671.2723; found 671.2720 .

5'-Deoxy-5'-N-[(tetraethyl(methylene bisphosphonate))]adenosine (22) The title compound was obtained as a white solid ( $89 \mathrm{mg}, 74 \%)$ from compound 21 (146.2 $\mathrm{mg}, 0.2 \mathrm{mmol}$ ) using general procedure A (with a ratio of $\left.\mathrm{TFA} / \mathrm{H}_{2} \mathrm{O}, 9 / 1\right)$. Purification was achieved by column chromatography with $\mathrm{CH}_{2} \mathrm{Cl}_{2} / \mathrm{MeOH}(90 / 10) . \mathrm{R}_{\mathrm{f}}\left(\mathrm{CH}_{2} \mathrm{Cl}_{2} / \mathrm{MeOH}, 9 / 1\right) 0.22$. ${ }^{1} \mathrm{H}$ NMR $\left(500 \mathrm{MHz}, \mathrm{CD}_{3} \mathrm{OD}\right): \delta 8.32(\mathrm{~s}, 1 \mathrm{H}, \mathrm{H}-2), 8.29(\mathrm{~s}, 1 \mathrm{H}, \mathrm{H}-8), 5.94$ -5.93 ( $\left.m, 1 \mathrm{H}, \mathrm{H}-1^{\prime}\right), \mathrm{H}-2^{\prime}$ signal in $\mathrm{H}_{2} \mathrm{O}$ peak, $4.39-4.38$ (m, $\left.1 \mathrm{H}, \mathrm{H}-3^{\prime}\right)$, $4.24-4.14\left(\mathrm{~m}, 9 \mathrm{H}, \mathrm{O}-\mathrm{CH}_{2}-\mathrm{CH}_{3}\right.$ and $\left.\mathrm{H}-4^{\prime}\right), 3.38-3.34\left(\mathrm{~m}, 1 \mathrm{H}, \mathrm{H}-5^{\prime}\right), 3.06$ - $3.03\left(\mathrm{~m}, 1 \mathrm{H}, \mathrm{H}-5^{\prime}\right), 1.33-1.27\left(\mathrm{~m}, 12 \mathrm{H}, \mathrm{CH}_{3}\right) .{ }^{13} \mathrm{C} \mathrm{NMR}(126 \mathrm{MHz}$, $\mathrm{CD}_{3} \mathrm{OD}$ ): $\delta 157.0(\mathrm{C}-6), 153.6(\mathrm{C}-2), 150.6(\mathrm{C}-4), 142.2(\mathrm{C}-8), 120.9$ (C-
5), 90.8 (C-1'), 86.4 (C-4'), 74.6 (C-2'), 72.9 (C-3'), 64.9 - 64.5 (m, O$\left.\mathrm{CH}_{2}-\mathrm{CH}_{3}\right), 52.6-52.5\left(\mathrm{~m}, \mathrm{CHP}\right.$ and $\left.\mathrm{C}-5^{\prime}\right), 16.8-16.7\left(\mathrm{~m}, \mathrm{CH}_{3}\right) .{ }^{31} \mathrm{P}$ NMR (202 MHz, CD $\left.{ }_{3} \mathrm{OD}\right): \delta 20.3-19.2(\mathrm{~m}, 2 \mathrm{P})$. Q-TOF MS E+: m/z $553.19(\mathrm{M}+\mathrm{H})^{+}$. HRMS Q-TOF MS E': calculated for $\mathrm{C}_{19} \mathrm{H}_{35} \mathrm{~N}_{6} \mathrm{O}_{9} \mathrm{P}_{2}$ $[\mathrm{M}+\mathrm{H}]^{+}$553.1941; found, 553.1938 .

5'-Deoxy-5'-N-(methylene bisphosphonate)adenosine (Tetra sodium salts) (9) The title compound was obtained as a white solid $(79 \mathrm{mg}$, quantitative yield) from compound $22(82 \mathrm{mg}, 0.15 \mathrm{mmol})$ using general procedure B (but with 20 eq. trimethylsilyl bromide). Purification was achieved by reverse-phase column chromatography with $\mathrm{H}_{2} \mathrm{O}$ followed by ion exchange on DOWEX 50WX2 ( $\mathrm{Na}^{+}$form). $\mathrm{Rf}\left(\mathrm{iPrOH} / \mathrm{NH}_{4} \mathrm{OH} / \mathrm{H}_{2} \mathrm{O}\right.$, 6/1/3) 0.36. ${ }^{1} \mathrm{H}$ NMR $\left(400 \mathrm{MHz}, \mathrm{D}_{2} \mathrm{O}\right): \delta 8.38(\mathrm{~s}, 1 \mathrm{H}, \mathrm{H}-8), 8.36(\mathrm{~s}, 1 \mathrm{H}, \mathrm{H}-$ 2), $6.13\left(\mathrm{~d}, J=5.7 \mathrm{~Hz}, 1 \mathrm{H}, \mathrm{H}-1^{\prime}\right), \mathrm{H}-2$ ' signal in $\mathrm{D}_{2} \mathrm{O}$ peak, $4.62-4.58(\mathrm{~m}$, $\left.1 \mathrm{H}, \mathrm{H}-4^{\prime}\right), 4.52-4.50\left(\mathrm{~m}, 1 \mathrm{H}, \mathrm{H}-3^{\prime}\right), 3.99-3.84\left(\mathrm{~m}, 2 \mathrm{H}, \mathrm{H}-5^{\prime}\right), 3.62(\mathrm{t}, J=$ $17.7 \mathrm{~Hz}, 1 \mathrm{H}, \mathrm{CHP}$ ). 13C NMR (151 MHz, D2O): $\delta 154.2$ (C-6), 151.6 (C2), 147.2 (C-4), 139.22 (C-8), 117.7 (C-5), 87.3 (C-1'), 78.4 (C-4'), 72.1 (C-2'), 69.9 (C-3'), 53.4 (CHP), 48.3 (C-5'). ${ }^{31} \mathrm{P}$ NMR (162 MHz, D $2 \mathrm{O}$ ): $\delta$ $7.28(\mathrm{P}), 7.07$ (P). Q-TOF MS E:: m/z $439.05(\mathrm{M}-\mathrm{H})$-. HRMS Q-TOF MS $\mathrm{E}:$ : calculated for $\mathrm{C}_{11} \mathrm{H}_{17} \mathrm{~N}_{6} \mathrm{O}_{9} \mathrm{P}_{2}[\mathrm{M}-\mathrm{H}]-439.0532$ found; 439.0536 .

5'-O-[(phosphorylacetate)]adenosine (trisodium salt) (23) This compound was obtained according to the procedure describe by Debarge et al. ${ }^{[18]}$ Characterizations $\left({ }^{1} \mathrm{H}\right.$ and MS) were in agreement with the literature. ${ }^{1} \mathrm{H}$ NMR $\left(400 \mathrm{MHz}, \mathrm{D}_{2} \mathrm{O}\right): \delta 8.62(\mathrm{~s}, 1 \mathrm{H}, \mathrm{H}-8$, dia1 or dia2), $8.60(\mathrm{~s}, \mathrm{H}-8,1 \mathrm{H}$, dia1 or dia2), $8.18(\mathrm{~s}, 2 \mathrm{H}, \mathrm{H}-2$, dia1 + dia2), 6.07 (s, $1 \mathrm{H}$, $\mathrm{H}-1^{\prime}$, dia1 or dia2), $6.06\left(\mathrm{~s}, 1 \mathrm{H}, \mathrm{H}-1^{\prime}\right.$, dia1 or dia2), $\mathrm{H}-2^{\prime}$ signal in $\mathrm{D}_{2} \mathrm{O}$ peak, $4.53-4.45\left(\mathrm{~m}, 2 \mathrm{H}, \mathrm{H}-4^{\prime}\right.$, dia1 or dia2), $4.34-4.30\left(\mathrm{~m}, 2 \mathrm{H}, \mathrm{H}-3^{\prime}\right.$, dia1 or dia2), $3.99-3.94$ (m, 2H, CHP, dia1 or dia2), $3.90-3.61(\mathrm{~m}, 4 \mathrm{H}$, $\mathrm{H}-5$, dia1 + dia2). HRMS Q-TOF MS $\mathrm{E}^{+}$calculated for $\mathrm{C}_{12} \mathrm{H}_{17} \mathrm{~N}_{5} \mathrm{O}_{9} \mathrm{P}$ $[\mathrm{M}+\mathrm{H}]+406.0764$ found; 406.0763 .

\section{2'-Arabino-fluoro-5'- $\mathrm{N}$-[(bisphosphono)methyl]-2-chloro-2',5'-}

dideoxyadenosine (24) The title compound was synthesized from commercially available Clofarabine according to procedure detailed in the SI. $\mathrm{R}_{\mathrm{f}}\left(\mathrm{iPrOH} / \mathrm{NH}_{4} \mathrm{OH} / \mathrm{H}_{2} \mathrm{O}, 7 / 1 / 2\right) 0.04 .{ }^{1} \mathrm{H}$ NMR $\left(600 \mathrm{MHz}, \mathrm{D}_{2} \mathrm{O}\right): \delta 8.53$ (s, $1 \mathrm{H}, \mathrm{H}-8), 6.46\left(\mathrm{dd}, J=16.1,4.1 \mathrm{~Hz}, 1 \mathrm{H}, \mathrm{H}-1^{\prime}\right), 5.36-5.26(\mathrm{~m}, 1 \mathrm{H}, \mathrm{H}-$ $\left.2^{\prime}\right), 4.72-4.66\left(\mathrm{~m}, 1 \mathrm{H}, \mathrm{H}-3^{\prime}\right), 4.41-4.38\left(\mathrm{~m}, 1 \mathrm{H}, \mathrm{H}-4^{\prime}\right), 3.67-3.51(\mathrm{~m}, 2 \mathrm{H}$, $\left.\mathrm{H}^{\prime} 5^{\prime}\right), 3.05\left(\mathrm{~d}, J=10.8 \mathrm{~Hz}, 4 \mathrm{H}, \mathrm{N}-\mathrm{CH}_{2}\right) \cdot{ }^{13} \mathrm{C} \mathrm{NMR}\left(151 \mathrm{MHz}, \mathrm{D}_{2} \mathrm{O}\right) \delta 156.4$ (C-2), 153.8 (C-6), 149.9 (C-4), 142.0 (C-8), 117.1 (C-5), 94.5 (d, $J=$ 191.3 Hz, C-2'), 82.2 (d, $\left.J=17.1 \mathrm{~Hz}, \mathrm{C}-1^{\prime}\right), 80.1$ (C-4'), 75.6 (d, $J=25.4$ $\left.\mathrm{Hz}, \mathrm{C}-3^{\prime}\right), 57.4$ (C-5'), 55.4 (d, J=137.1 Hz, H2C-N). ${ }^{31} \mathrm{P}$ NMR (400 MHz, MeOD) $\delta$ 13.2. ${ }^{19} \mathrm{~F} \mathrm{NMR} \mathrm{(400} \mathrm{MHz,} \mathrm{MeOD)} \delta$-198.4. Q-TOF MS E:: $\mathrm{m} / \mathrm{z}$ $489.03(\mathrm{M}-\mathrm{H})$. HRMS Q-TOF MS E-. Calculated for $\mathrm{C}_{12} \mathrm{H}_{17} \mathrm{~N}_{6} \mathrm{O}_{8} \mathrm{FP} 2 \mathrm{Cl}[\mathrm{M}-$ H] 489.0256; found: 489.0256

Molecular modelling and docking. All compounds were modelled using the VegaZZ molecular modelling suite and subjected to energy minimization of the potential energy by 500 steps of steepest-descent gradient followed by 5,000 steps of conjugate gradient algorithm (Tripos force field and Gasteiger-Marsili partial charges) until convergence with a gradient tolerance of $0.001 \mathrm{kcal} / \mathrm{mol}$. $\AA$ ). ${ }^{[19]}$ Molecular docking was achieved with Gold v5.6 (Genetic Optimization for Ligand Docking) from the Cambridge Crystallographic Data Centre (CCDC, Software Limited) on the crystal structure of CD73 (PDB 4H2I) solved at $2 \AA$ of resolution in a closed conformation (crystal form III from Knapp K. et al. ${ }^{[8]}$ ). Target binding site was defined by a spherical area around the $\mathrm{CZ}$ atom of Arg395 (as this residue is located in the center of the substrate binding site and in contact with phosphonate oxygen's of APCP) with a radius 10 $\AA$ and scrutiny of cavity. Water molecules from the crystal were preserved and allowed for translation / rotation freedoms within a $2 \AA$ window. The search of best docking poses was performed by executing 50 runs of genetic algorithms (search-based optimization technique based on Genetics and natural selection) and the ranking of docking solutions was computed by the GoldScore fitness function by using the complete linkage clustering method from the RMSD matrix of generated solutions. ${ }^{[20]}$ The GoldScore scoring function was selected as it has been optimized for the prediction of ligand binding positions and takes into 
account factors such as $\mathrm{H}$-bonding energy, van der Waals energy, metal interaction and ligand torsion strain (thus, the score reflects the theoretical affinity and is expressed as arbitrary units in GOLD). The highest-ranked poses were selected for structural analysis and interaction measurements with CD73 amino acids using the PyMol Molecular Graphics System (v1.8, Schrödinger, LLC).

Enzymatic inhibition assays. CD73 activity was evaluated using the purified recombinant enzyme as previously described ${ }^{[17]}$ by quantifying the inorganic phosphate release upon AMP hydrolysis. Briefly, the amount of inorganic phosphate produced was determined by using the Green Malachite Phosphate assay kit (Gentaur) and a standard phosphate concentration range $(0-50 \mu \mathrm{M})$ for normalizing raw data. To determine the enzymatic inhibition, recombinant CD73 (2 nM, final concentration) was incubated in a reaction buffer (Tris $50 \mathrm{mM}, \mathrm{pH} 7.5$, $\mathrm{NaCl} 100 \mathrm{mM}, \mathrm{MgCl}_{2} 1 \mathrm{mM}, \mathrm{CaCl}_{2} 1 \mathrm{mM}$ and $\left.\mathrm{ZnCl}_{2} 5 \mu \mathrm{M}\right)$ in the absence or in the presence of the indicated compounds at various concentrations for 1 minute at room temperature. The reaction was started by addition of the substrate, AMP $(100 \mu \mathrm{M})$ and incubated for 2 minutes at $37^{\circ} \mathrm{C}$ under gentle shaking. Then, reaction was stopped by addition of the Green Malachite reagent (containing a strong acid) and inorganic phosphate produced was quantified by reading the optical density (OD) at $630 \mathrm{~nm}$ on a plate reader (Tecan Sunrise). The percentage of enzymatic inhibition was calculated by using the following formula: 1 -

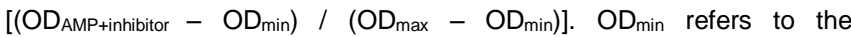
absorbance without enzymatic reaction (background signal) and OD $D_{\max }$, the full reaction in absence of inhibitor. To determine $\mathrm{IC}_{50}$ values of the inhibitory compounds, GraphPad Prism was used.

Cell-based assays. Inhibition of CD73 activity on cells were assessed using CD73-positive human breast cancer MDA-MB-231 cells. Cells (25,000 per well) were seeded in 96-well plates in $100 \mu \mathrm{L}$ complete media and left to adhere overnight. After 4 washes with $100 \mu \mathrm{L}$ buffer $\left(\mathrm{MgCl}_{2} 2 \mathrm{mM}, \mathrm{NaCl} 120 \mathrm{mM}, \mathrm{KCl} 5 \mathrm{mM}\right.$, glucose $10 \mathrm{mM}$, Hepes $20 \mathrm{mM}$ $\mathrm{pH}$ 7.4), cells were incubated with $100 \mu \mathrm{L}$ containing (or not) $200 \mu \mathrm{M}$ AMP and $100 \mu \mathrm{M}$ inhibitors for 10 minutes. Then, the reaction was stopped by incubating the plate on ice, and inorganic phosphate was quantified with the Green Malachite Phosphate Assay kit (Gentaur). The inhibition activity was calculated as $1-\left(O D_{A M P+i n h i b i t o r}-O D_{\text {inhibitor }}\right) /\left(O D_{A M P}\right.$ - OD only cells). Every condition was performed in triplicate and at least three times.

Potential toxicity of studied compounds to human cells was estimated after exposing the same cells (3000 cells in 96 well plates) to $100 \mu \mathrm{M}$ of compounds for $72 \mathrm{~h}$. Then, the relative number of cells was determined using the MTT assay.

\section{Acknowledgements}

Institutional funds from the Institut National du Cancer (INCa, project $n \circ$ 2017-151) and the Agence Nationale de la Recherche (ANR Programme Blanc 2011-SIMI7, «cN-II Focus» supported this work. We are thankful for the financial support provided by the University of Montpellier (PhD grants for RG and FG). VTN thanks the Vietnamese Government \& the USTH for a $\mathrm{PhD}$ fellowship. RR was supported by a fellowship from the Ligue Contre le Cancer.

\section{Conflict of Interest}

The authors declare no conflict of interest
Keywords: 5 '-ectonucleotidase $\cdot$ enzyme inhibitors • nucleos(t)ide analogue $\bullet$ immunotherapy $\bullet$ cancer

\section{References:}

[1] L. Antonioli, P. Pacher, E. S. Vizi, G. Haskó, Trends in molecular medicine 2013, 19, 355-367.

[2] aL. Antonioli, S. V. Novitskiy, K. F. Sachsenmeier, M. Fornai, C. Blandizzi, G. Haskó, Drug Discovery Today 2017, 22, 1686-1696; bD. Allard, B. Allard, P.-O.

Gaudreau, P. Chrobak, J. Stagg, Immunotherapy 2016, 8, 145-163; cC. Patricia Frasson, F. Fabricio, N. Gustavo Machado das, A. Saulo, K. Daniel Fabio, B. Ana Maria Oliveira, E.-L. Vera Lucia, Current Medicinal Chemistry 2015, 22, 1776-1792; dX. Zhi, S. Chen, P. Zhou, Z. Shao, L. Wang, Z. Ou, L. Yin, RNA interference of ecto-5'nucleotidase (CD73) inhibits human breast cancer cell growth and invasion, Vol. 24, 2007.

[3] I. Perrot, H.-A. Michaud, M. Giraudon-Paoli, S. Augier, A. Docquier, L. Gros, R. Courtois, C. Déjou, D. Jecko, O. Becquart, H. Rispaud-Blanc, L. Gauthier, B. Rossi, S. Chanteux, N. Gourdin, B. Amigues, A. Roussel, A. Bensussan, J.-F. Eliaou, J. Bastid, F. Romagné, Y. Morel, E. Narni-Mancinelli, E. Vivier, C. Paturel, N. Bonnefoy, Cell Reports 2019, 27, 2411-2425.e2419.

[4] C. M. Hay, E. Sult, Q. Huang, K. Mulgrew, S. R. Fuhrmann K. A. McGlinchey, S. A. Hammond, R. Rothstein, J. RiosDoria, E. Poon, N. Holoweckyj, N. M. Durham, C. C. Leow, G. Diedrich, M. Damschroder, R. Herbst, R. E. Hollingsworth, K. F. Sachsenmeier, Oncolmmunology 2016, 5, e1208875.

[5] aR. lannone, L. Miele, P. Maiolino, A. Pinto, S. Morello, American journal of cancer research 2014, 4, 172-181; bB. Zhang, Cancer Research 2010, 70, 6407-6411.

[6] aS. Bhattarai, M. Freundlieb, J. Pippel, A. Meyer, A. Abdelrahman, A. Fiene, S.-Y. Lee, H. Zimmermann, G. G. Yegutkin, N. Sträter, A. El-Tayeb, C. E. Müller, Journal of Medicinal Chemistry 2015, 58, 6248-6263; bA. Junker, C. Renn, C. Dobelmann, V. Namasivayam, S. Jain, K. Losenkova, H. Irjala, S. Duca, R. Balasubramanian, S. Chakraborty, F. Börgel, H. Zimmermann, G. G. Yegutkin, C. E. Müller, K. A. Jacobson, Journal of Medicinal Chemistry 2019, 62, 3677-3695

[7] aR. J. Billedeau, J. Li, L. Chen, 2018, p. 405; bS. C. Cacatian, David A.; Jia, Lanqi; Morales-Ramos, Angel Singh, Suresh B.; Venkatraman, Shankar; Xu, Zhenrong; Zheng, Yajun, 2015.

[8] K. Knapp, M. Zebisch, J. Pippel, A. El-Tayeb, Christa E. Müller, N. Sträter, Structure 2012, 20, 2161-2173.

[9] aA. P. Townsend, S. Roth, H. E. L. Williams, E. Stylianou, N. R. Thomas, Organic Letters 2009, 11, 2976-2979; bM. van Haren, L. Q. van Ufford, E. E. Moret, N. I. Martin, Organic \& Biomolecular Chemistry 2015, 13, 549-560.

[10] M. Stichelberger, D. Desbouis, V. Spiwok, L. Scapozza, P. A. Schubiger, R. Schibli, Journal of Organometallic Chemistry 2007, 692, 1255-1264.

[11] J. J. Bronson, L. M. Ferrara, H. G. Howell, P. R. Brodfuehrer, J. C. Martin, Nucleosides and Nucleotides 1990, 9, 745-769.

[12] S. Manfredini, N. Solaroli, A. Angusti, F. Nalin, E. Durini, S Vertuani, S. Pricl, M. Ferrone, S. Spadari, F. Focher, A. Verri, E. De Clercq, J. Balzarini, Antiviral Chemistry and Chemotherapy 2003, 14, 183-194.

[13] E. Bálint, E. Fazekas, L. Drahos, G. Keglevich, Heteroatom Chemistry 2013, 24, 510-515.

E. Bálint, Á. Tajti, A. Adám, I. Csontos, K. Karaghiosoff, M. Czugler, P. Ábrányi-Balogh, G. Keglevich, Beilstein Journal of Organic Chemistry 2017, 13, 76-86.

[15] E. Bálint, Á. Tajti, A. Dzielak, G. Hägele, G. Keglevich, Beilstein Journal of Organic Chemistry 2016, 12, 1493 1502.

[16] I. Nowak, M. J. Robins, Organic Letters 2003, 5, 33453348. 
[17] C. Dumontet, S. Peyrottes, C. Rabeson, E. Cros-Perrial, P. Y. Géant, L. Chaloin, L. P. Jordheim, European Journal of Medicinal Chemistry 2018, 157, 1051-1055.

[18] S. Debarge, J. Balzarini, A. R. Maguire, The Journal of Organic Chemistry 2011, 76, 105-126.

[19] aJ. Gasteiger, M. Marsili, Tetrahedron 1980, 36, 32193228; bA. Pedretti, L. Villa, G. Vistoli, Journal of

Computer-Aided Molecular Design 2004, 18, 167-173.

[20] aG. Jones, P. Willett, R. C. Glen, Journal of Molecular Biology 1995, 245, 43-53; bG. Jones, P. Willett, R. C. Glen, A. R. Leach, R. Taylor, Journal of Molecular Biology 1997, 267, $727-748$. 


\section{Entry for the Table of Contents}

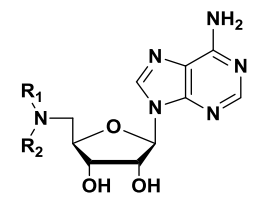

$\mathbf{R}_{1}=\mathrm{H}, \mathbf{R}_{\mathbf{2}}=\mathrm{CH}_{2}-\mathrm{COO}^{-}$, or $\mathrm{COCH}_{2}-\mathrm{P}(\mathrm{O}) \mathrm{OEt}\left(\mathrm{O}^{-}\right)$, or $\mathrm{COCH}_{2}-\mathrm{P}(\mathrm{O})\left(\mathrm{O}^{-}\right)_{2}$, or $\mathrm{CH}_{2}-\mathrm{P}(\mathrm{O}) \mathrm{OEt}\left(\mathrm{O}^{-}\right)$, or $\mathrm{CH}_{2}-\mathrm{P}(\mathrm{O})\left(\mathrm{O}^{-}\right)_{2}$, or $\mathrm{CH}\left(\mathrm{COO}^{-}\right) \mathrm{P}(\mathrm{O}) \mathrm{OEt}\left(\mathrm{O}^{-}\right)$, or $\mathrm{CH}\left(\mathrm{COO}^{-}\right) \mathrm{P}(\mathrm{O})\left(\mathrm{O}^{-}\right)_{2}$, or $\mathrm{CH}\left[\mathrm{P}(\mathrm{O})\left(\mathrm{O}^{-}\right)_{2}\right]_{2}$

$$
\mathbf{R}_{\mathbf{1}}=\mathbf{R}_{\mathbf{2}}=\mathrm{CH}_{2}-\mathrm{P}(\mathrm{O})\left(\mathrm{O}^{-}\right)_{2}
$$

Low to modest inhibitors of $\mathrm{CD73}$

Novel nucleos(t)ide analogues based on a 5'-aminoadenosine scaffold were synthesized and their ability to inhibit 5'ectonucleotidase CD73 was assessed. 